\title{
Convective uplift of pollution from the Sichuan Basin into the Asian monsoon anticyclone during the StratoClim aircraft campaign
}

\author{
Keun-Ok Lee ${ }^{1,2}$, Brice Barret ${ }^{1}$, Eric L. Flochmoën ${ }^{1}$, Pierre Tulet ${ }^{2}$, Silvia Bucci ${ }^{3}$, Marc von Hobe , Corinna Kloss $^{4,5}$, \\ Bernard Legras $^{3}$, Maud Leriche ${ }^{1,8}$, Bastien Sauvage ${ }^{1}$, Fabrizio Ravegnani ${ }^{6}$, and Alexey Ulanovsky ${ }^{7}$ \\ ${ }^{1}$ Laboratoire d'Aérologie, Université de Toulouse, CNRS, UPS, Toulouse, France \\ ${ }^{2}$ Laboratoire de l'Atmosphère et des Cyclones, UMR8105, CNRS, Météo-France, \\ Université de la Réunion, Saint-Denis de La Réunion, France \\ ${ }^{3}$ Laboratoire de Météorologie Dynamique, UMR CNRS 8539, IPSL ENS-PSL/Sorbonne Université/ \\ Ecole Polytechnique/Ecole des Ponts Paris Tech, Paris, France \\ ${ }^{4}$ Institute for Energy and Climate Research (IEK-7), Forschungszentrum Jülich GmbH, 52425 Jülich, Germany \\ ${ }^{5}$ LPC2E, CNRS/Université d'Orléans, Orléans, France \\ ${ }^{6}$ Institute for Atmospheric Sciences and Climate of the National Research Council (CNR-ISAC), Bologna, Italy \\ ${ }^{7}$ Central Aerological Observatory (CAO), Moscow, Russia \\ ${ }^{8}$ Centre pour l'étude et la simulation du climat à l'échelle régionale, Université du Québec à Montréal, Montréal, Canada
}

Correspondence: Keun-Ok Lee (keunok.lee@univ-reunion.fr) and Brice Barret (brice.barret@aero.obs-mip.fr)

Received: 11 June 2020 - Discussion started: 23 June 2020

Revised: 21 January 2021 - Accepted: 21 January 2021 - Published: 4 March 2021

\begin{abstract}
The StratoClim airborne campaign took place in Nepal from 27 July to 10 August 2017 to document the physical and chemical properties of the South Asian upper troposphere-lower stratosphere (UTLS) during the Asian summer monsoon (ASM). In the present paper, simulations with the Meso-NH cloud-chemistry model at a horizontal resolution of $15 \mathrm{~km}$ are performed over the Asian region to characterize the impact of monsoon deep convection on the composition of Asian monsoon anticyclone (AMA) and on the formation of the Asian tropopause aerosol layer (ATAL) during the StratoClim campaign. StratoClim took place during a break phase of the monsoon with intense convective activity over South China and Sichuan. Comparisons between brightness temperatures (BTs) at $10.8 \mu \mathrm{m}$ observed by satellite sensors and simulated by Meso-NH highlight the ability of the model to correctly reproduce the life cycle of deep convective clouds. A comparison between $\mathrm{CO}$ and $\mathrm{O}_{3}$ concentrations from Meso-NH and airborne observations (StratoClim and IAGOS (In-service Aircraft for a Global Observing System)) demonstrates that the model captures most of the observed variabilities. Nevertheless, for both gases, the model tends to overestimate the concentrations and misses some thin CO plumes related to local convective events prob-
\end{abstract}

ably because the resolution is too coarse, but the convective uplift of pollution is very well captured by the model. We have therefore focused on the impact of Sichuan convection on the AMA composition. A dedicated sensitivity simulation showed that the 7 August convective event brought large amounts of CO deep into the AMA and even across the $380 \mathrm{~K}$ isentropic level located at $17.8 \mathrm{~km}$. This Sichuan contribution enhanced the $\mathrm{CO}$ concentration by $\sim 15 \%$ to reach more than $180 \mathrm{ppbv}$ over a large area around $15 \mathrm{~km}$ height. It is noteworthy that Meso-NH captures the impact of the diluted Sichuan plume on the CO concentration during a StratoClim flight south of Kathmandu, highlighting its ability to reproduce the transport pathway of Sichuan pollution. According to the model, primary organic aerosol and black carbon particles originating from Sichuan are transported following the same pathway as CO. The large particles are heavily scavenged within the precipitating part of the convective clouds but remain the most important contributor to the particle mass in the AMA. Over the whole AMA region, the $7 \mathrm{Au}$ gust convective event resulted in a $0.5 \%$ increase in $\mathrm{CO}$ concentration over the $10-20 \mathrm{~km}$ range that lasted about $2 \mathrm{~d}$. The impact of pollution uplift from three regions (India, China, and Sichuan) averaged over the first $10 \mathrm{~d}$ of August has also 
been evaluated with sensitivity simulations. Even during this monsoon break phase, the results confirm the predominant role of India relative to China with respective contributions of $11 \%$ and $7 \%$ to $\mathrm{CO}$ concentration in the $10-15 \mathrm{~km}$ layer. Moreover, during this period a large part $(35 \%)$ of the Chinese contribution comes from the Sichuan Basin alone.

\section{Introduction}

Deep convection plays a key role in venting chemical constituents from the boundary layer (BL) to the upper troposphere-lower stratosphere (UTLS), where they have a significant chemical and radiative impact (Mason and Anderson, 1963; Dickerson and Delany, 1987; Randel and Park, 2006; Su et al., 2011; Fadnavis et al., 2013; Gu et al., 2016; Bian et al., 2020). With updraught velocities that can largely exceed $10 \mathrm{~m} \mathrm{~s}^{-1}$, vertical uplift from deep convection can occur in durations ranging from minutes to hours (Markowski and Richardson, 2010).

The Asian summer monsoon (ASM) circulation covers large parts of South and East Asia from the tropics to the subtropics. It consists of a cyclonic flow and convergence in the lower troposphere associated with a strong anticyclonic circulation and divergence in the UTLS called the Asian monsoon anticyclone (AMA). This circulation is coupled with persistent deep convection over the south Asian region during summer (June to September; Hoskins and Rodwell, 1995). The tropopause height above the ASM is relatively high $(16-17.5 \mathrm{~km})$ and the AMA extends into the lower stratosphere spanning from around 200 to $70 \mathrm{hPa}(12-$ $18.5 \mathrm{~km}$ a.s.l.), i.e. approximately the whole UTLS (Highwood and Hoskins, 1998; Randel and Park, 2006; Bian et al., 2012).

Due to the strength and size of the AMA, which spans the region from the Pacific to the Mediterranean, the influence of the monsoon on the UTLS composition is a significant contribution of the global budget. In the past 15 years, numerous studies based on satellite data have shown that the AMA had a strong BL composition signature. For instance, using microwave limb sounder (MLS) data, Wright et al. (2011) have documented relatively high water vapour mixing ratios (about 4.2-4.5 ppmv) and atmospheric infrared sounder (AIRS) data show low ozone $\left(\mathrm{O}_{3}\right)$ (Randel et al., 2001) within the AMA. With their high and unprecedented UTLS sensitivity, the MLS carbon monoxide (CO) observations clearly allowed the detection of the BL signature in the AMA (Park et al., 2004; Li et al., 2005; Randel and Park, 2006; Barret et al., 2008; Randel et al., 2010). More recently, observations from the CALIPSO (Cloud-Aerosol Lidar and Infrared Pathfinder Satellite Observation) spaceborne lidar evidenced the Asian tropopause aerosol layer (ATAL) distributed around $16 \mathrm{~km}$ within the AMA (Vernier et al., 2015).
Most of the studies based on chemistry transport simulations have demonstrated that the BL pollution uplifted to the AMA was mostly from Indian or South Asian sources (Park et al., 2009; Yan and Bian, 2015; Barret et al., 2016). Aerosols in the UTLS have much longer residence times than in the lower troposphere and can therefore impact atmospheric chemistry and the Earth's climate with large spatial and temporal coverage (Rasch et al., 2008). Eastern Asia and China are highly polluted but less impacted by monsoon deep convection and therefore contribute less to the feeding of BL pollution into the UTLS. Nevertheless, deep convection is characterized by an important inter-annual variability. The active phase of the StratoClim (Stratospheric and upper tropospheric processes for better Climate predictions, http://www.stratoclim.org/, last access: 1 March 2021) airborne campaign took place during a monsoon break phase with particularly strong convective activity over the Sichuan Basin compared to Nepal and northern India (Lee et al., 2019; Bucci et al., 2020).

StratoClim aims to improve our knowledge of the key microphysical, chemical, and dynamical processes that control the composition of the AMA and of the ATAL and the impact of the ASM on the hydration of the stratosphere. During the campaign (from 27 July to 10 August 2017), eight dedicated flights were successfully carried out. Using StratoClim in situ measurements and convection-permitting numerical simulations, Lee et al. (2019) investigated the stratospheric hydration documented during flight \#7. They reported that the strong orographically triggered overshooting convection occurring in the Sichuan Basin (Fig. 1) transported more than $6 \mathrm{kt}$ of water vapour across the tropopause. Due to strong UTLS easterly winds south of the AMA, a large amount of water vapour ( $\geq 5.5 \mathrm{ppmv}$ ) was transported over Nepal even though a large part of the uplifted moisture was lost due to ice formation and sedimentation.

Sichuan is a highly populated (83 million according to 2017 estimates) and industrialized region with large cities such as Chengdu, Mianyang, and Nanchong, resulting in large amounts of pollutants stored in the basin at the mountain foothills. CO emissions from the MACCity (MACC/CityZEN EU projects) inventory (https://eccad3. sedoo.fr/, last access: 1 March 2021; Fig. 2) show the isolated large $\mathrm{CO}$ fluxes in this region (red box). We can therefore hypothesize that the unusual overshooting convection documented by Lee et al. (2019) resulted in the uplift of large amounts of pollutants into the AMA and its westward transport by the AMA easterlies. We therefore focused our investigation on the impact of the unusual Sichuan overshooting convection on the AMA composition during the StratoClim campaign. This is achieved by combining fine-scale cloud-chemistry simulations with the unprecedented wealth of measurement data.

Detailed descriptions of the observations and of the model simulations are given in Sect. 2. Section 3 presents a validation of the simulated convective clouds with satellite observa- 


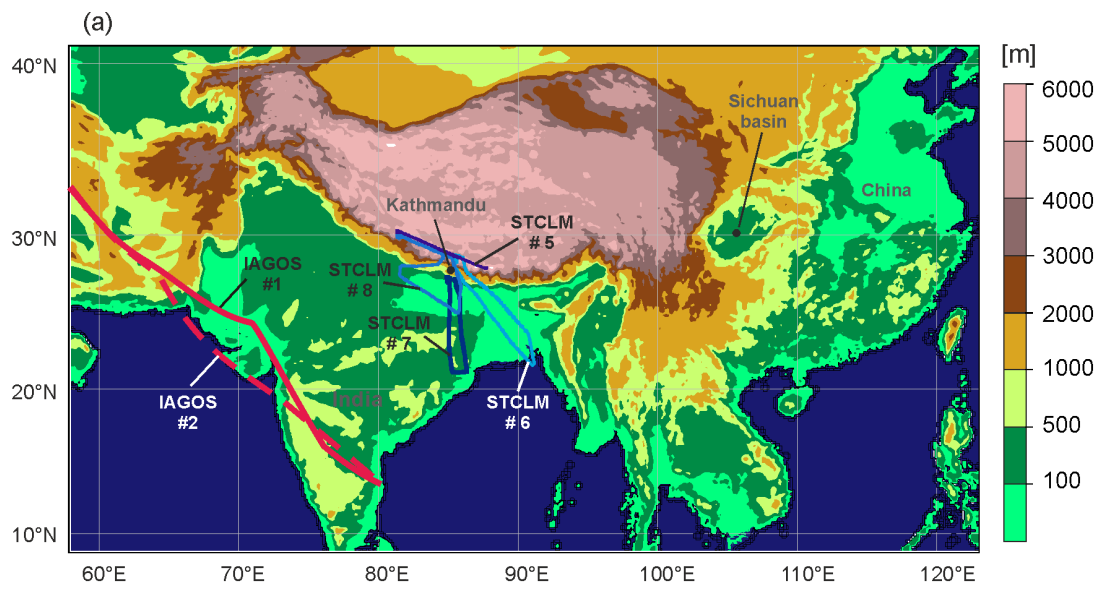

(b) STCLM \#5

03:00 UTC 4 Aug 2017

(c) STCLM \#6

08:00 UTC 6 Aug 2017
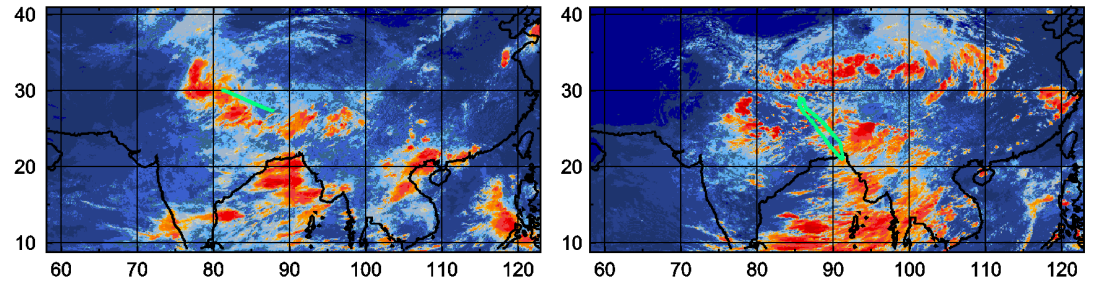

$[\mathrm{K}]$
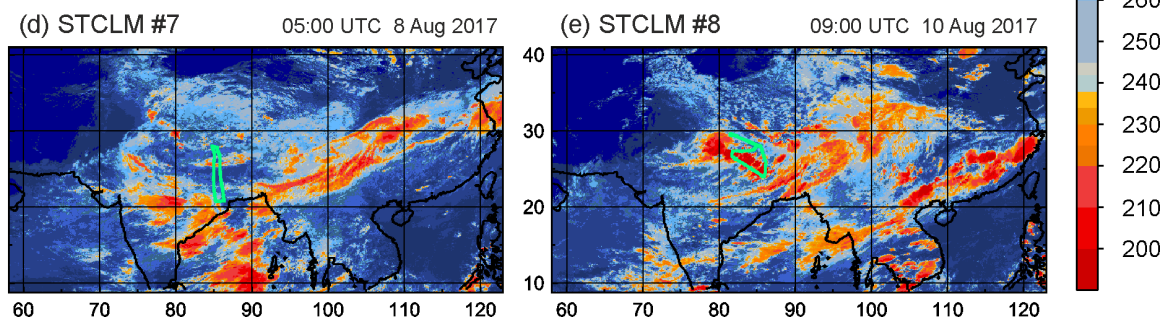

Figure 1. (a) Topography and domain considered in the Meso-NH numerical simulation with a resolution of $15 \mathrm{~km}$. The trajectory of the Geophysica flights \#5-\#8 during the StratoClim campaigns (indicated by STCLM) around and south of Kathmandu are shown by the bluish solid lines in (a), while the trajectory is displayed by green solid lines and overlapped on BT distribution at the time around each flight's departure in (b-e), respectively. In (a), two IAGOS flight tracks (to and from Madras in India) are indicted by the red solid and dashed line.

tions and of the simulated UTLS composition with airborne in situ measurements. In Sect. 4, we investigate the pollution uplift to the AMA by the strongest overshooting convective event in the Sichuan Basin. Section 5 is dedicated to quantifying the impact of broader regional sources on the UTLS composition. Finally, a summary and discussion of the findings of the present study are provided in Sect. 6 .

\section{Data and methods}

\subsection{Airborne observations: StratoClim and IAGOS}

\subsubsection{StratoClim measurements}

We will use data from M55-Geophysica flights \#5-\#8, which took place from Kathmandu in Nepal (Table 1; for the tracks see bluish lines marked STCLM in Fig. 1a and grey lines in Fig. 1b-e). During these flights, the AMICA (Airborne Mid-Infrared Cavity enhanced Absorption spectrometer) and FOZAN-II (Fast OZone ANalyzer) instruments measured the $\mathrm{CO}$ and $\mathrm{O}_{3}$ concentrations, respectively. The flights occurred during 03:00-07:25 UTC on 4 August for flight \#5 (Fig. 1b), 07:30-11:30 UTC on 6 August for flight \#6 (Fig. 1c), 04:3006:50 UTC on 8 August for flight \#7 (exceptionally no $\mathrm{O}_{3}$ measurement; Fig. 1d), and 08:40-12:30 UTC on 10 August for flight \#8 (Fig. 1e). Flights \#5 and \#7 flew in the region almost without tall clouds, while flights \#6 and \#8 flew in the cloudy neighbours.

CO concentration was measured by the AMICA instrument (Kloss et al., 2021) placed on top of the Geophysica aircraft. AMICA employs integrated cavity output spectroscopy (ICOS; O'Keefe et al., 1999) to measure various trace gases in the mid-infrared region. $\mathrm{CO}$ mixing ratios were retrieved from observed spectra using a transition 


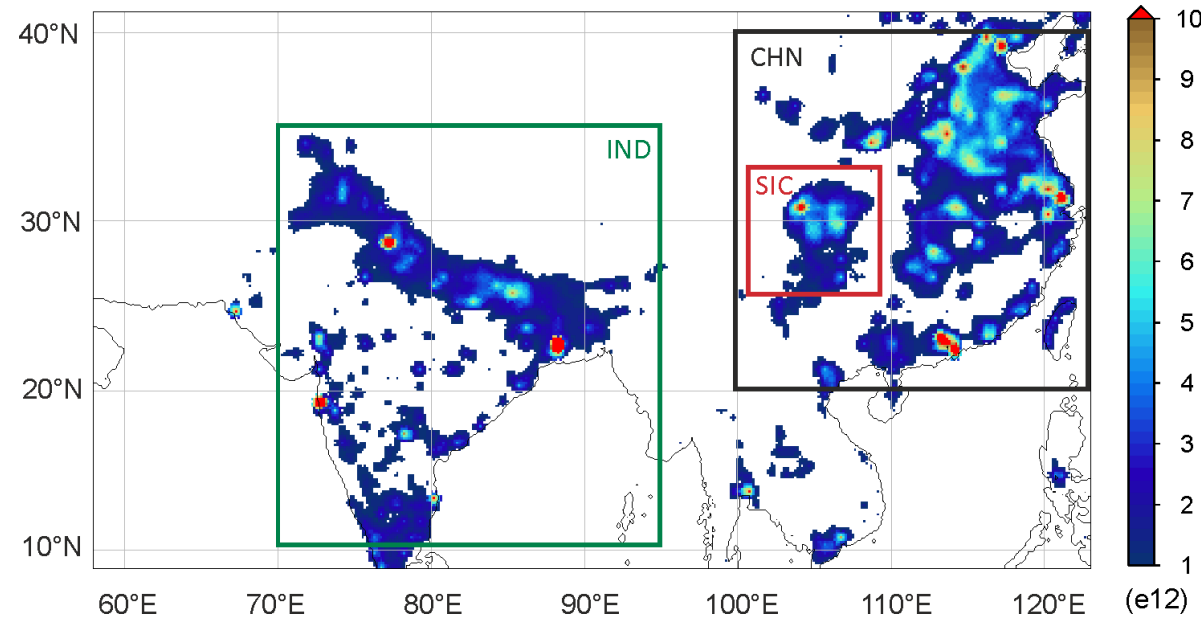

Figure 2. The emission map of CO concentration used for CNTL (control run). Inner boxes indicate the domain of no emission for the sensitivity experiments (see also Table 3) of the SIC06 and SIC01 (101-109 ${ }^{\circ}$ E, 26-33 ${ }^{\circ} \mathrm{N}$; red line), CHN01 (100-122 ${ }^{\circ}$ E, $20-40^{\circ}$ N; black line), and IND01 $\left(70-95^{\circ} \mathrm{E}, 10-35^{\circ} \mathrm{N}\right.$; green line) simulations. In the sensitivity experiment names, the first three letters stand for the area of interest, e.g. SIC for Sichuan, CHN for China, and IND for India, while the last two numbers stands for the first day of emission modification. For details, see Table 3.

Table 1. Duration and variables of StratoClim flights. For the flight track, see Fig. 1.

\begin{tabular}{lllll}
\hline Exp. & $\# 5$ & $\# 6$ & $\# 7$ & $\# 8$ \\
\hline Duration & $03: 00-07: 25$ UTC 4 August & 07:30-11:30 UTC 6 August & 04:30-06:50 UTC 8 August & 08:40-12:30 UTC 10 August \\
Variables & $\mathrm{CO}, \mathrm{O}_{3}$ concentration & $\mathrm{CO}, \mathrm{O}_{3}$ concentration & CO concentration & $\mathrm{CO}, \mathrm{O}_{3}$ concentration \\
\hline
\end{tabular}

at $2050.90 \mathrm{~cm}^{-1}$ with line parameters taken from the HITRAN (high-resolution transmission molecular absorption) 2012 database (Rothman et al., 2013) and no further calibration parameters. Accuracy was tested for a range of mixing ratios $(30-5000 \mathrm{ppb})$ prepared from a $5 \pm 0.05 \mathrm{ppm} \mathrm{CO}$ concentration standard (AirProducts) and is estimated to be better than $5 \%$ taking into account the uncertainty of the standard, upper limits for impurities in the dilution gas, and uncertainties in the mass flow controller (MFC) flows used for dilution. In this study, AMICA CO concentration data are used at $10 \mathrm{~s}$ time resolution and have a $1 \sigma$ precision of $\sim 20 \mathrm{ppb}$ that was mainly limited by electrical noise on the observed spectra.

The FOZAN-II is a chemiluminescence sensor for $\mathrm{O}_{3}$ monitoring at $1 \mathrm{~Hz}$ time resolution. It was developed by the Central Aerological Observatory, Russia, and the Institute of Atmospheric Science and Climate, Italy (Yushkov et al., 1999; Ulanovsky et al., 2001), and is jointly operated aboard Geophysica by scientists from the two institutes. FOZANII is a two-channel solid-state chemiluminescent instrument featuring a sensor based on Coumarin 307 dye on a celluloseacetate-based substrate and is equipped with a high-accuracy ozone generator for periodic calibration of each channel every 15 min during the flight, ensuring an accuracy better than $10 \mathrm{ppb}$ and a precision of $8 \%$. The measured concentration range is $10-500 \mu \mathrm{g} \mathrm{m}^{-3}$, the operating temperature range is
-95 to $+40^{\circ} \mathrm{C}$, and the operating pressure range is 1100 30 mbar (about $0-22 \mathrm{~km}$ ). The instrument was calibrated on the ground before and after each flight by means of an ozone generator and reference UV-absorption $\mathrm{O}_{3}$ monitor (Dasibi 1008-PC).

\subsubsection{IAGOS measurements}

A commercial aircraft equipped with an IAGOS (In-service Aircraft for a Global Observing System, https://www.iagos. org/, last access: 1 March 2021) instrumental package flew back and forth between Frankfurt in Germany and Madras in India (for the tracks, see the red solid and dashed lines in Fig. 1) from 09:18 UTC on 5 August to 05:22 UTC on 6 August 2017 with a short break at Madras from 18:20 to 20:20 UTC on 5 August 2017. In situ sensors aboard the aircraft measured the $\mathrm{CO}$ and $\mathrm{O}_{3}$ concentrations every 30 and $4 \mathrm{~s}$, respectively. The $\mathrm{CO}$ concentration analyser (Nedelec et al., 2003) is an improved version of a commercial Model 48CTL from Thermo Environmental Instruments based on the gas filter correlation principle of infrared absorption by the $4.67 \mu \mathrm{m}$ fundamental vibration-rotation band of $\mathrm{CO}$ concentration. The Model 48CTL is qualified by the US EPA designated method (EQSA-0486-060). The precision specification of the commercial instrument is within $\pm 5 \%$. 
The IAGOS $\mathrm{O}_{3}$ analyser (Thouret et al., 1998) is a dualbeam UV-absorption instrument (Thermo-Electron, model 49-103). The response time is $4 \mathrm{~s}$, and the concentration is automatically corrected for pressure and temperature influences. This instrument archives a precision of $\pm 2 \%$, an accuracy of $1 \mathrm{ppbv}$, and a minimum detectable concentration of 2 ppbv. This instrument provides high stability making the measurements accurate and reliable over long time periods.

\subsection{Spaceborne observations}

In order to document deep convective clouds, we used calibrated thermal infrared brightness temperature (BT) in the infrared window from geostationary satellites. In order to correctly cover the region between South and East Asia, BTs acquired by the Meteosat Second Generation (MSG) Spinning Enhanced Visible and Infrared Imager (SEVIRI) sensor were merged with BTs acquired by the Advanced Himawari Imager (AHI) sensor aboard Himawari-8 that acquires images every $10 \mathrm{~min}$. MSG-SEVIRI has been centred at $41.5^{\circ} \mathrm{E}$ since July 2016, while the Himawari-8 field of view is centred at $140^{\circ} \mathrm{E}$. Together, merged at $90^{\circ} \mathrm{E}$, they cover the whole region of interest. Data are projected onto a $0.1^{\circ}$ grid using a closest neighbour interpolation and sampled every hour. The two satellites are matched at the longitude $90^{\circ} \mathrm{E}$. Cold BTs below $230 \mathrm{~K}$ are indicative of high cloud tops associated with deep convection (e.g. Lee et al., 2016, 2019).

\subsection{High-resolution cloud-chemistry simulations}

The coupled cloud-chemistry non-hydrostatic Meso-NH model (Lac et al., 2018) was used to simulate the deep monsoon convection and the AMA composition. The simulations are performed within a large domain covering India and China (Fig. 1, 8.8-40.9 $9^{\circ}, 58-122.9^{\circ} \mathrm{E}$ ) therefore encompassing the StratoClim flight tracks and the deep convective clouds over the Sichuan Basin with a $15 \mathrm{~km}$ horizontal resolution ( $\sim 7$ million grid points; see Table 2 for a detailed description of the model). The vertical grid has 64 stretched levels (Gal-Chen and Somerville, 1975) with a resolution of $100 \mathrm{~m}$ close to the surface stretched to $450 \mathrm{~m}$ in the UTLS up to $24.2 \mathrm{~km}$. The control simulation (referred to as CNTL) covered the period from 00:00 UTC on 27 July 2017 to 00:00 UTC on 15 August 2017 with three-dimensional outputs every $3 \mathrm{~h}$, assigning the first few days as a spinup time.

The initial and lateral boundary conditions for meteorology are provided by the operational European Centre for Medium-Range Weather Forecasts (ECMWF) analyses every $6 \mathrm{~h}$. The initial and boundary conditions for gaseous chemical species including inorganic nitrogen species (e.g. $\mathrm{O}_{3}, \mathrm{CO}, \mathrm{SO}_{2}, \mathrm{NH}_{3}$, NMVOCs - non-methane Volatile Organic Compounds), primary aerosol species (e.g. black carbon - BC, primary organic aerosols - POA), and secondary aerosol species (e.g. inorganic, secondary or-
Table 2. Model setup specifications.

\begin{tabular}{ll}
\hline Horizontal resolution & $15 \mathrm{~km}$ \\
Vertical resolution & 100 to $450 \mathrm{~m}$ \\
Temporal resolution & $40 \mathrm{~s}$ \\
Emission & MACCity, MEGAN, FGEDv3 \\
Meteorology boundary & ECMWF analyses \\
Chemical boundary & MOZART-4 \\
Chemical scheme & ReLACS 2 \\
Aerosol modules & ORILAM, ORILAM-SOA
\end{tabular}

ganic aerosols - SOA) are taken from MOZART-4 (Model for Ozone and Related chemical Tracers, version 4) (Emmons et al., 2010). Boundary chemical fields are forced every $6 \mathrm{~h}$. Surface emissions of atmospheric compounds are taken from the ECCAD (Emissions of atmospheric Compounds and Compilation of Ancillary Data) database (https: //eccad.aeris-data.fr, last access: 1 March 2021) at a $0.5^{\circ}$ horizontal grid spacing. For anthropogenic and biomass burning emissions, we have used the MACCity inventory (MACC/CityZEN EU projects; van der Werf et al., 2010; Lamarque et al., 2010; Granier et al., 2011; Diehl et al., 2012) corresponding to August 2017. MACCity provides "offline" emissions for gases such as alkanes, alkenes, alcohols, aldehydes, ketones, and aromatics lumped into 21 species and for primary aerosol species. The MEGAN v2 model (Model of Emissions of Gases and Aerosols from Nature; Guenther et al., 2006) provides offline monthly net biogenic emissions of gases ( $\mathrm{NO}_{x}$ and VOCs) and aerosols. Finally, the monthly GFEDv3 (Global Fire Emissions Database, version 3) inventory (Van der Werf et al., 2010) was used for biomass burning emissions (e.g. CO, NMVOCs, BC, POA).

For gas phase chemistry, we used the ReLACS2 scheme (Regional Lumped Atmospheric Chemical Scheme 2) as described by Suhre et al. (1998) and Tulet et al. (2003). ReLACS2 (Tulet et al., 2006) is derived from a reduction of the CACM scheme (Griffin et al., 2002). It includes 82 prognostic gaseous chemical species and 363 reactions enabling the formation of SOA precursors to be addressed. The processes controlling the aerosol population, emissions, nucleation, coagulation, condensation, dry deposition, sedimentation, diffusive transport, and wet deposition are modelled by the ORILAM scheme (Organic-Inorganic Lognormal Aerosol Model; Tulet et al., 2005, 2006, 2010). The impaction scavenging by raindrops depends mainly on Brownian motion, interception, and inertial impaction following a formula originally described by Slinn (1983). Two lognormal modes of particles are considered: mode \#1 (i.e. the Aitken mode) of smaller particles with an initial mean radius of $0.036 \mu \mathrm{m}$ and standard deviation $(\sigma)$ of 1.86 and mode \#2 (i.e. accumulation mode) of larger particles with an initial mean radius of $0.385 \mu \mathrm{m}$ and $\sigma$ of 1.29 . The coarse mode of the particles is strongly leached by impaction, while the Aitken and nucleation modes are collected by Brownian 
motion. The gas-to-particle conversion for inorganic species is handled by the EQSAM model (Equilibrium Simplified Aerosol Model; Metzger et al., 2002). To simulate SOA formation, the partitioning of the low-volatility organic species between the gas and aerosol phases is based on the thermodynamic equilibrium scheme MPMPO (Model to Predict the Multiphase Partitioning of Organics; Griffin et al., 2003, 2005). The dry deposition of chemical species is treated according to the resistance concept of Wesely (1989) in the SURFEX model, which treats all surface processes (Masson et al., 2013). The deposition depends on the boundary layer turbulence and on the molecular diffusion, which lead gases and particles to effective surface deposition.

The meteorological conditions are initialized by the ECMWF analyses and clouds are formed in the first time steps of the model (spinup) after a saturation adjustment. Deep convection is parameterized following the KainFritsch-Bechtold scheme (Bechtold et al., 2001). In order to obtain reasonable simulations of the impact of convection on tropospheric composition, subgrid convective transport needs to be computed (Grell and Freitas, 2014; Li et al., 2018). Scavenging by subgrid wet convective updraughts is applied within the convective mass transport algorithm in order to prevent soluble tracers from being transported to the top of the convective updraught and then dispersed on the grid scale. The transport model provides wet convective air mass fluxes through each grid level in the updraught. The one-moment bulk microphysical scheme (Pinty and Jabouille, 1998) governs the equations of six water categories (water vapour, cloud water, rainwater, pristine ice, snow, and graupel). For each particle type, the size follows a generalized gamma distribution while power-law relationships allow the mass and fall speed to be linked to the diameters. Except for cloud droplets, each condensed water species has a nonzero fall speed. In this study, Meso-NH simulations have a horizontal grid spacing of $15 \mathrm{~km}$ with parameterized convection resulting from a tradeoff between a high resolution for detailed dynamics of the mesoscale convective systems and efficient run over a large domain covering the entire AMA. There is certainly an effect of not explicitly considering aerosol activation on clouds that is difficult to quantify without performing a higher resolution simulation. However, in deep convection, high vertical velocities create significant supersaturation and tend to activate much of the available aerosol spectrum. The turbulence parameterization is based on a 1.5-order closure (Cuxart et al., 2000) of the turbulent kinetic energy equation and uses the Bougeault and Lacarrere (1989) mixing length. Momentum variables are transported with the weighted essentially nonoscillatory (WENO) scheme (Shu and Osher, 1988) to transport momentum variables, while other variables are transported with the piecewise parabolic method (PPM) scheme (Colella and Woodward, 1984). This combination of meteorological schemes has already shown its capability to simulate heavy precipitation events in both real and idealized frameworks (Ducrocq et al., 2008; Bresson et al., 2012; Lee et al., 2018, 2019; among others). The SEVIRI-MSG BTs are compared to synthetic BTs computed offline using the Radiative Transfer for TIROS Operational Vertical Sounder (RTTOV) code version 11.3 (Saunders et al., 2013) from the simulation outputs (Chaboureau et al., 2008).

\section{Evaluation of the CNTL experiment}

\subsection{Clouds and deep convection}

Deep convective cloud (BTs $\leq 210 \mathrm{~K}$ ) are detected over the Sichuan Basin at 12:00 UTC on 7 August 2017 by combined observations from the MSG-SEVIRI and Himawari sensors (box, Fig. 3a). Between 12:00 and 18:00 UTC, multiple deep convective cells develop and the area of low BT values $(\leq 210 \mathrm{~K})$ covers most of the Sichuan Basin at 18:00 UTC (Fig. 3c). It is worth noting the spatial coincidence of deep convection and large Sichuan Basin CO emissions (red box, Fig. 2). From 18:00 UTC (Fig. 3e and g) on, the convective systems gradually stretch horizontally with the strong UTLS easterlies. During Geophysica flight \#7 (8 August 06:00 UTC, Fig. 3g), cloud (BT $\leq 210 \mathrm{~K}$ ) originating from the Sichuan convective cells reach the region south of Kathmandu $\left(\sim 85^{\circ} \mathrm{E}\right)$, while some thin clouds (BT $\leq 250 \mathrm{~K}$ ) partially cover the region $\sim 85^{\circ} \mathrm{E}$ on the flight track. The BT distributions derived from the CNTL simulation (Fig. 3b, d, f, and h) show that the life cycle of deep convective clouds that occurred over the Sichuan Basin during 7-8 August is correctly reproduced by the simulation. While the CNTL simulation overestimates the extension of convective cloud at 12:00 UTC on 7 August (Fig. 3a and b), it realistically captures the area covered by the deep convective clouds (BT $\leq 210 \mathrm{~K}$ ) at 18:00 UTC (Figs. $3 \mathrm{c}$ and d) and the thinner clouds corresponding to the convection outflow, which are horizontally stretched to the west between 00:00 and 06:00 UTC on 8 August (Fig. 3e-h).

\subsection{Chemical composition}

The simulated chemical data were interpolated to the height, latitude, and longitude of the aircraft rounded to the nearest $40 \mathrm{~s}$ time step of the model for a direct comparison. The comparison between observed and simulated CO concentration (Fig. 4) shows that CNTL succeeds in reproducing the $\mathrm{CO}$ variations along the tracks of all flights. In particular, the simulation reproduces very well the anti-correlation between the $\mathrm{CO}$ concentration and the altitude as expected from a tropospheric tracer.

Flight \#5 (Fig. 4a) consists of a step-by-step ascent from 16 to $20 \mathrm{~km}$ with the observed $\mathrm{CO}$ concentrations (green circles) gradually decreasing from 90 to the stratospheric background of 10 to $20 \mathrm{ppb}$. The $\mathrm{CO}$ concentration from the CNTL simulation follows the observed CO, deceasing from 150 to $\sim 20 \mathrm{ppb}$. During the fast ascent and descent part of 
(a) 12:00 UTC 7 Aug 2017

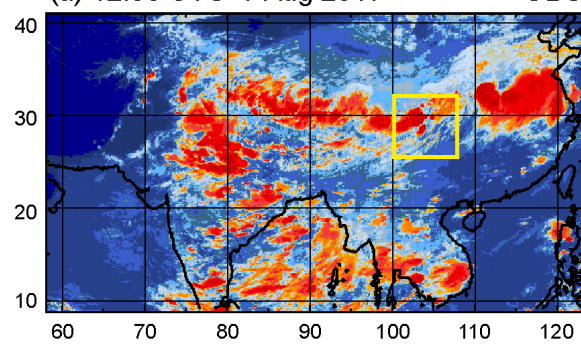

(c) 18:00 UTC 7 Aug 2017

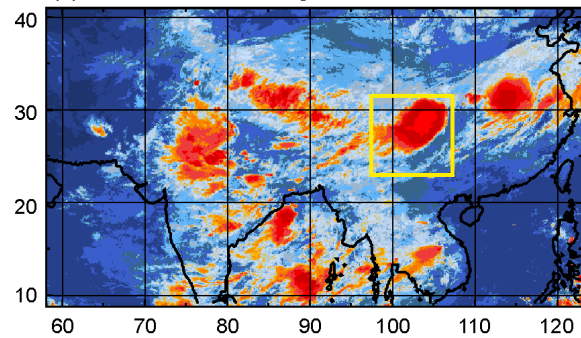

(e) 00:00 UTC 8 Aug 2017

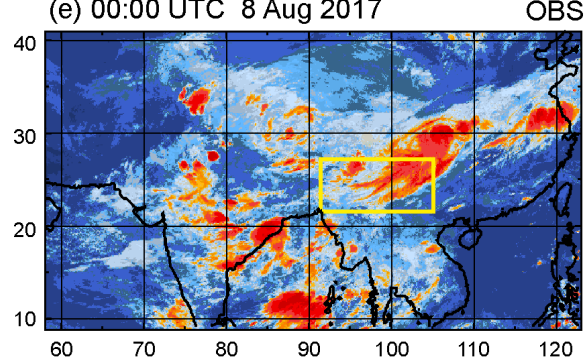

(g) 06:00 UTC 8 Aug 2017

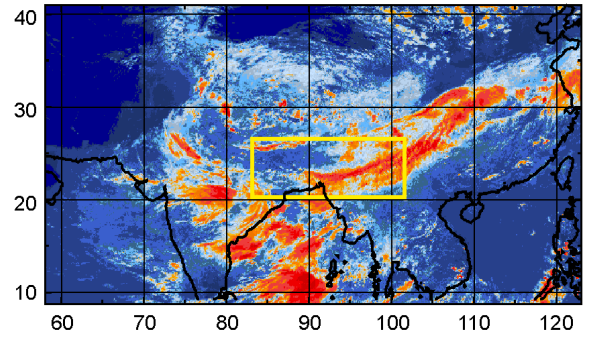

(b) 12:00 UTC 7 Aug 2017

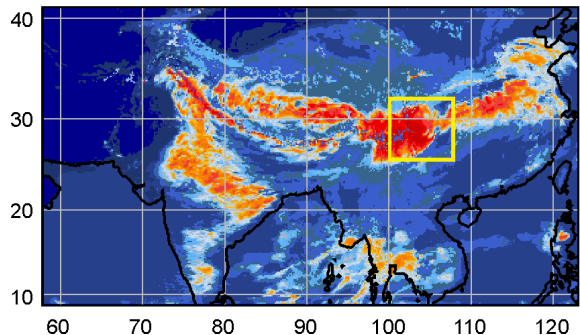

(d) 18:00 UTC 7 Aug 2017
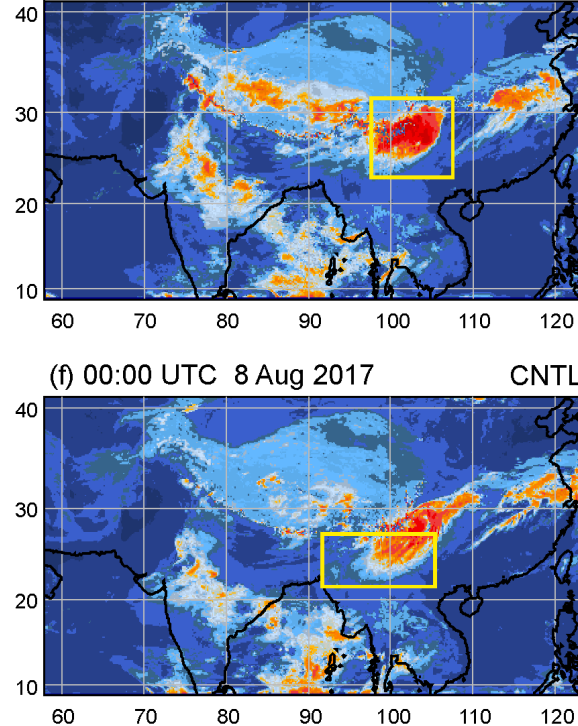

(h) 06:00 UTC 8 Aug 2017

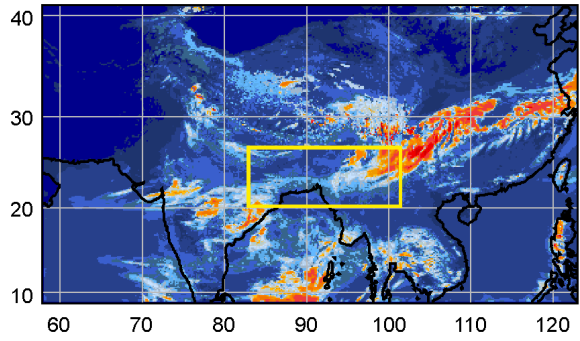

200210220230240250260270280290300

Figure 3. Infrared BT composite images using MSG-SEVIRI and Himawari (a, c, e, g) and Meso-NH (b, d, f, h) at (a, b) 12:00 UTC on 7 August, (c, d) 18:00 UTC on 7 August, $(\mathbf{e}, \mathbf{f})$ 00:00 UTC on 8 August, and $(\mathbf{g}, \mathbf{h})$ 06:00 UTC on 8 August. The area of interest is marked by a yellow box.

the flights, at altitudes below $15 \mathrm{~km}$, the simulated concentrations exceed the observed concentrations. Flight \#6 flew mostly at about $17 \mathrm{~km}$ altitude with observed $\mathrm{CO}$ concentrations of about $60 \mathrm{ppb}$. The CNTL simulation generally overestimates this low $\mathrm{CO}$ concentration by $\sim 20 \mathrm{ppbv}$. At around $34000 \mathrm{~s}$ the aircraft goes into a dive at $15 \mathrm{~km}$ and the $\mathrm{CO}$ concentration rapidly increases up to about $140 \mathrm{ppb}$ in both the measurement and simulation. Before and after the dive, the observations display two peaks of $120 \mathrm{ppbv} \mathrm{CO}$ concentration, which are not well reproduced by the simu- lation, where increases are closer in time to the dive and last longer. Flight \#7 (Fig. 4c) is characterized by excursions within the UTLS between 15 and $20 \mathrm{~km}$. Both measurement and simulation show the clear anti-correlation between altitude and $\mathrm{CO}$ concentration, which ranges from 10 to 130 ppbv. Finally, during flight \#8 (Fig. 4d), the aircraft remains at $\sim 17 \mathrm{~km}(86 \mathrm{hPa})$ during the $35000-40000 \mathrm{~s}$ period near the Kathmandu foothills. During this period, the measured CO concentrations remain within a $30-50$ ppb background except for three $90 \mathrm{ppb}$ peaks at the beginning. Dur- 

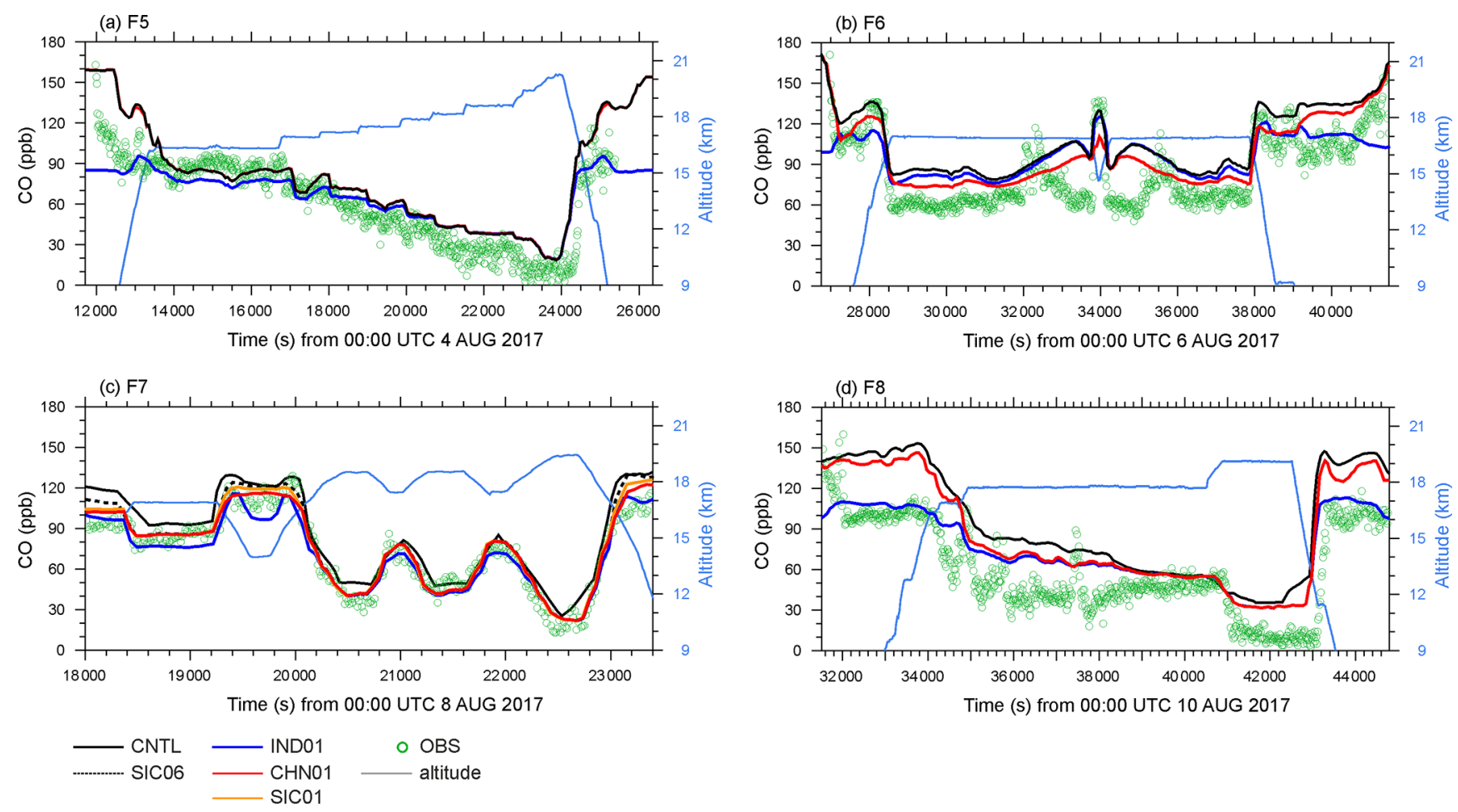

Figure 4. Comparison of $\mathrm{CO}$ concentration (ppbv) of AMICA-measured (green circles) and Meso-NH-derived (black lines) along the StratoClim flight tracks (a) \#5 on 4 August, (b) \#6 on 6 August, (c) \#7 on 8 August, and (d) \#8 on 10 August 2017 (for the locations, see Fig. 1). The simulated CO concentration by SIC01, CHN01, and IND01 along the flight tracks are displayed by orange, red, and blue solid lines, respectively. Flight altitudes are displayed by light blue lines. In (c), the SIC06-produced CO concentration along the flight track is displayed by a dotted line.

ing the same time, $\mathrm{CO}$ concentration from the CNTL simulation gradually decreases from 90 to $55 \mathrm{ppb}$. As for flight \#6 it appears that the model is not able to reproduce the short $\mathrm{CO}$ peaks but instead produces longer and smoother increases. For flight \#8, the model missed the very short $\mathrm{CO}$ peaks at $\sim 17 \mathrm{~km}$. This is probably linked to a model grid spacing that is too coarse and not adapted to capture fine plumes. Also note that flights \#6 and \#8 flew into the populated region of convective clouds (BT $\leq 210 \mathrm{~K}$; see Fig. 1c and e). The location of convective clouds strongly affects the concentrations of chemical properties. For flight \#8, at the beginning and end of the flight, the simulation overestimates the concentrations by up to $30 \mathrm{ppb}$, which is also clear for the tropospheric profiles during takeoff and landing. This is probably linked to the emission inventory.

Contrarily to $\mathrm{CO}$ concentration as a stratospheric tracer, $\mathrm{O}_{3}$ measured by the FOZAN instrument (red circles in Fig. 5) is highly correlated to flight altitude for the three StratoClim flights (blue line). It is particularly clear with flight \#5 where $\mathrm{O}_{3}$ is increasing stepwise with the aircraft altitude until it reaches $1055 \mathrm{ppbv}$ at $20.1 \mathrm{~km}$. The CNTL simulation (black lines) is able to capture accurately those observed variations with good agreement with the measured $\mathrm{O}_{3}$ except in the troposphere below about $12 \mathrm{~km}$ where it overestimates the low $\mathrm{O}_{3}$ concentrations, which are decreasing down to $0 \mathrm{ppbv}$. During flight \#7, the $\mathrm{O}_{3}$ variations (80-600 ppbv) related to the altitude excursions of the aircraft are very well captured by the model, but the modelled $\mathrm{O}_{3}$ is highly biased by 50 to $80 \mathrm{ppbv}$ during this flight. It is noteworthy that $\mathrm{O}_{3}$ concentrations measured around Kathmandu (about $22500 \mathrm{~s}, 19.3 \mathrm{~km}$ ) are one-third lower during flight \#7 than during flight \#5. This is probably linked to the transport of relatively fresh BL air masses from the Tibetan Plateau (Bucci et al., 2020). Observed $\mathrm{CO}$ concentrations corroborate this hypothesis with lower CO concentration during flight \#5 (Fig. 4a) than during flight \#7 (Fig. 4c) around Kathmandu. During flight \#8 (Fig. 5c), near constant $\mathrm{O}_{3}$ concentrations are measured at the near constant flight altitudes, i.e. $\sim 120 \mathrm{ppbv}$ at $18 \mathrm{~km}$ and $\sim 400 \mathrm{ppbv}$ at $19 \mathrm{~km}$. Correlatively, $\mathrm{O}_{3}$ from the CNTL simulation ranges from 170 to $400 \mathrm{ppbv}$, overestimating the concentrations by $\sim 100 \mathrm{ppbv}$ during $38000-40000 \mathrm{~s}$ when the aircraft is flying at $18 \mathrm{~km}$ over the southern foothills of Kathmandu ( $\sim 200$ ppbv instead of $\sim 100$ ppbv).

During the StratoClim period, we benefit from two commercial flights from the IAGOS programme across the southwestern part of the AMA (Fig. 6) at the near constant altitude of $\sim 11.5 \mathrm{~km}$. Both measurements and the CNTL simulation display clear and coincident $\mathrm{CO}$ concentration enhancements 


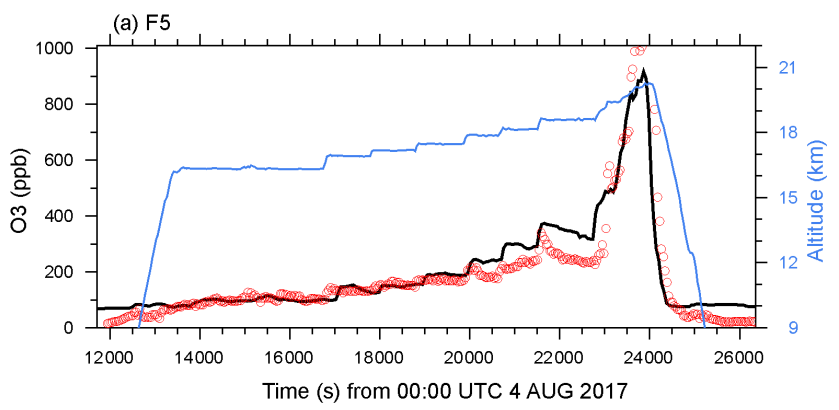

which is consistent with the high biases relative to FOZAN $\mathrm{O}_{3}$ from StratoClim Geophysica flights.

In summary, comparisons with $10.8 \mu \mathrm{m}$ BT images from geostationary satellites have shown that the location and intensity of deep convective clouds are very well reproduced by the CNTL simulation suggesting that the model is able to reproduce the convective uplift of BL pollutants into the UT. Comparisons with StratoClim and IAGOS in situ observations have highlighted the ability of the model to largely reproduce $\mathrm{CO}$ and $\mathrm{O}_{3}$ concentrations UTLS variations from 10 to $21 \mathrm{~km}$. It is noteworthy that the CNTL simulation tends to overestimate $\mathrm{CO}$ concentration by up to $20 \mathrm{ppbv}$ in the UTLS especially around Bangladesh (flight \#6) at $\sim 17 \mathrm{~km}$ and at the southern foothills of Kathmandu (flight \#8) at $\sim 18 \mathrm{~km}$ and $40 \mathrm{ppbv}$ in the troposphere at takeoff and landing. $\mathrm{O}_{3}$ is overestimated by $\sim 20 \mathrm{ppbv}$ in the AMA and up to $100 \mathrm{ppbv}$ south of Kathmandu at $\sim 18 \mathrm{~km}$ (flights \#7 and \#8). Overestimation also reaches $45 \mathrm{ppbv}$ in the extratropical UTLS at $\sim 11.5 \mathrm{~km}$ relative to IAGOS data.

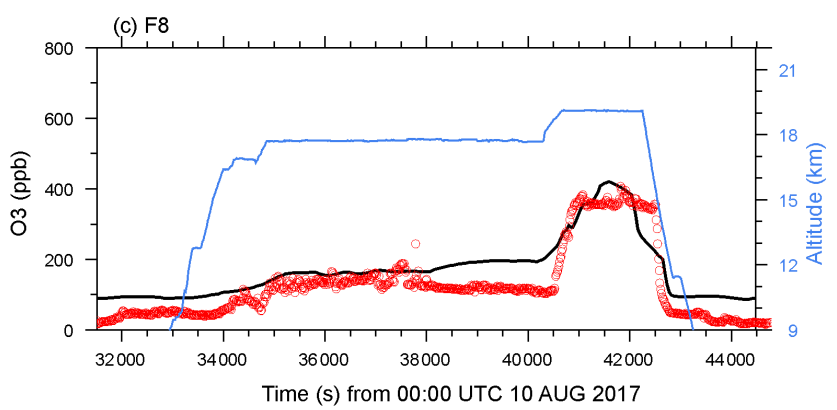

Figure 5. Comparison of measured (red circles) and Meso-NHderived (black lines) ozone (ppb) along the StratoClim flight tracks (a) \#5 on 4 August, (b) \#7 on 8 August, and (c) \#8 on 10 August 2017 (for the locations, see Fig. 1). Flight altitudes are displayed by light blue lines.

within the AMA range. At the northwestern edge of the AMA $\left(30^{\circ} \mathrm{N}, 60^{\circ} \mathrm{E}\right.$; red arrows), the aircraft penetrates the tropical air masses from the extratropical UTLS and CO concentration rapidly increases from 80 to $110 \mathrm{ppb}$. At the southwestern edge of the AMA ( $\sim 15^{\circ} \mathrm{N}, 75^{\circ} \mathrm{E}$; black arrows) $\mathrm{CO}$ concentration gradually decreases from AMA high concentrations to lower tropical UT concentrations. The model correctly captures both rapid extratropical UTLS to AMA and slow AMA to tropical UT transitions along the flight tracks at the bottom of the AMA $(\sim 11.5 \mathrm{~km})$. The model overestimates the $\mathrm{CO}$ concentrations by 5 to $20 \mathrm{ppb}$ within the AMA range.

IAGOS-measured $\mathrm{O}_{3}$ (Fig. 6) slowly increases from $46 \mathrm{ppbv}$ in the tropical UT south of the AMA to about $90 \mathrm{ppbv}$ in the extratropical UTLS north of the AMA. The CNTL simulation nonetheless displays the same increasing trend with an overestimation of $\sim 20 \mathrm{ppbv} \mathrm{O}_{3}$ in the AMA and tropical UT and $\sim 50 \mathrm{ppbv}$ in the extratropical UTLS, 
(a) IAGOS \#1

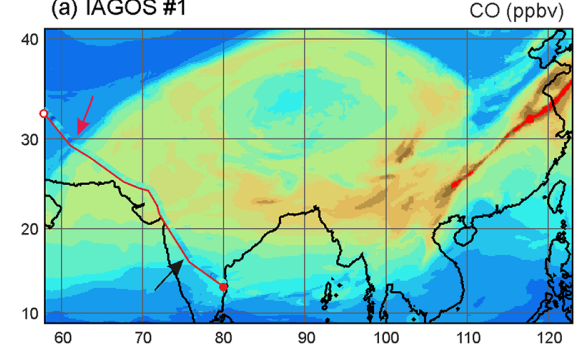

(c) IAGOS \#2

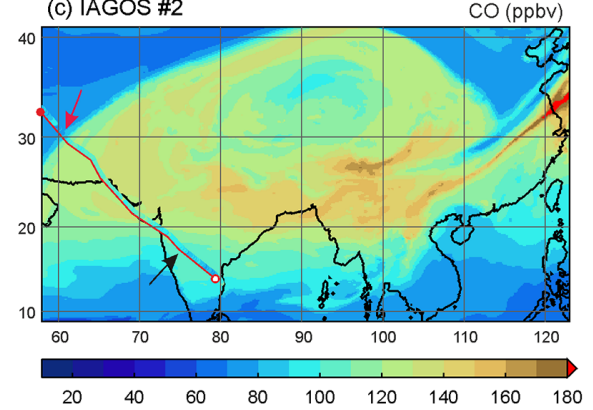

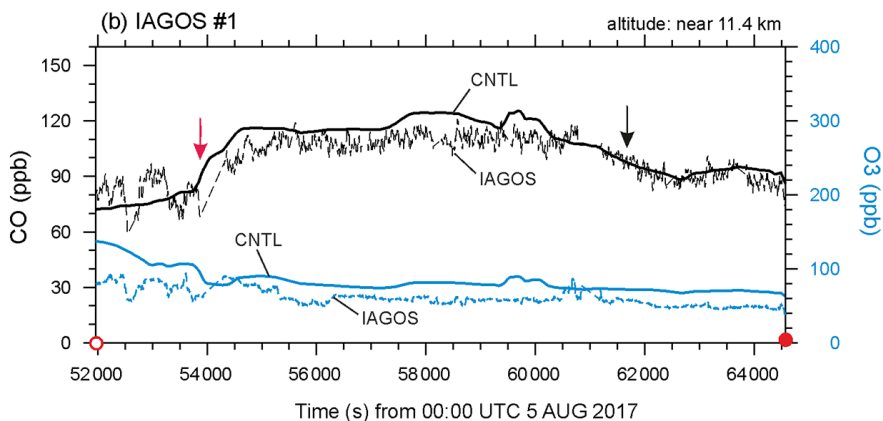

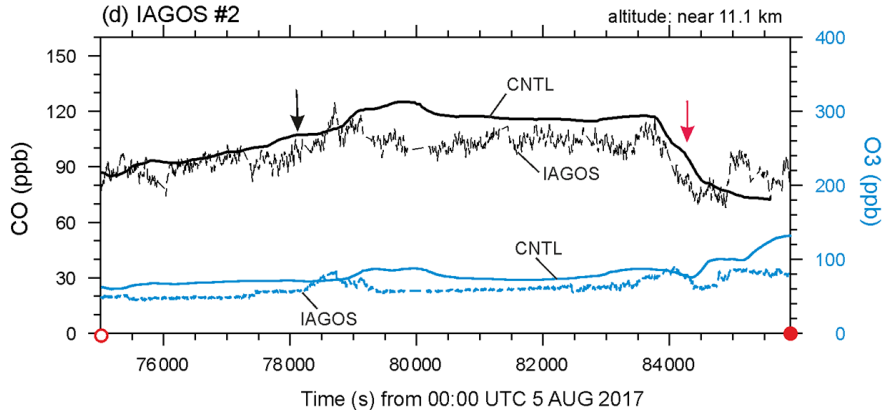

Figure 6. IAGOS-measured (dashed lines) and Meso-NH-derived (solid lines) $\mathrm{CO}$ concentration (black lines) and $\mathrm{O}_{3}$ concentration (blue lines) along the IAGOS flight tracks on 5 August 2017. In (a) and (c), Meso-NH-derived CO concentration at the altitude of $11.1 \mathrm{~km}$ are displayed by shaded areas, while the IAGOS-measured CO concentration every $5 \mathrm{~min}$ are displayed by coloured circles along the track (red lines). In (b) and (d), IAGOS-measured $\mathrm{CO}$ and $\mathrm{O}_{3}$ concentrations every $4 \mathrm{~s}$ are displayed. In (a-d), the starting (ending) point of each flight within the domain is marked by open (closed) red circles, while the location of the steep (gradual) change of CO concentration is marked by red (black) arrows.

Table 3. List of sensitivity experiments and the duration and area of emission modifications. For the area of modification, see Fig. 2.

\begin{tabular}{lllll}
\hline Exp. & SIC06 & SIC01 & CHN01 & IND01 \\
\hline Duration & $\begin{array}{l}\text { From 18:00 UTC 6 August } \\
\text { to 00:00 UTC 8 August }\end{array}$ & $\begin{array}{l}\text { From 00:00 UTC 1 August } \\
\text { to 00:00 UTC 8 August }\end{array}$ & $\begin{array}{l}\text { From 00:00 UTC 1 August } \\
\text { to 00:00 UTC 8 August }\end{array}$ & $\begin{array}{l}\text { From 00:00 UTC 1 August } \\
\text { to 00:00 UTC 8 August }\end{array}$ \\
\hline Area & Sichuan Basin & Sichuan Basin & Central China & India \\
\hline
\end{tabular}

ference with the CNTL simulation (= [CNTL minus SIC06] over [CNTL]) are displayed in Fig. 7 (third column). During the whole period, the $\mathrm{CO}$ patch is highly coincident with the deep convective system that develops over the Sichuan Basin (delimited by a box). In order to document the vertical transport of pollution and its relationship with convective clouds, Fig. 8 displays the longitude-altitude cross sections of simulated $\mathrm{CO}$ concentrations and winds together with cloud contours (mixing ratio of ice content of $10 \mathrm{mg} \mathrm{kg}^{-1}$ ) corresponding to the locations of the $\mathrm{CO}$ patches of Fig. 7 (for the locations, see black solid lines in Fig. 7).

The AMA covers a large area $\left(20-35^{\circ} \mathrm{N}, 60-120^{\circ} \mathrm{E}\right)$ characterized by the anticyclonic circulation, and the enhanced CO concentrations (Fig. 7b, e, h, k, and n) from the embryo of convection at 06:00 UTC on 7 August are dissipated at 06:00 UTC on 8 August. At the mature stage of convection (18:00 UTC on 7 August), CO concentrations reach maximum values of $195 \mathrm{ppbv}$ within the convective core.
At the start of the deep convective event (06:00 UTC on 7 August) the embryo of the CO patch (enhancement of $\sim$ $5 \mathrm{ppbv}$ ) is coincident with low BT values ( $\leq 210 \mathrm{~K}$, Fig. 7a), enhanced CO concentrations ( $\geq 140 \mathrm{ppbv}$ ) and the northerly winds $\left(\leq 15 \mathrm{~m} \mathrm{~s}^{-1}\right.$, Fig. $\left.7 \mathrm{~b}\right)$ from the eastern edge of the AMA over the Sichuan Basin (box, Fig. 7a and b). The vertical cross section across the $\mathrm{CO}$ patch embryo (Fig. 8a, latitude $29.5^{\circ} \mathrm{N}$ ) highlights the accumulation of a large amount of pollution in the Sichuan Basin at the foothills of the Tibetan plateau (around $104^{\circ} \mathrm{E}$ ). A plume of enhanced CO concentrations is most visible between 6 and $9 \mathrm{~km}$ below the convective cloud, which clearly overshoots the $380 \mathrm{~K}$ isentrope above the plume. During the development of convection (12:00-18:00 UTC, Fig. 7d-i), low BT $(\leq 210 \mathrm{~K})$ and enhanced $\mathrm{CO}$ concentrations $(\geq 160 \mathrm{ppbv})$ with a large Sichuan contribution of 5-25 ppbv (or 5\%-15\%) spread over most of the Sichuan. At 12:00 UTC (Fig. 8b), the convective clouds cross the $380 \mathrm{~K}$ isentrope over a larger area 
BT $10.8 \mu \mathrm{m}$

(a) 06:00 UTC 7 Aug 2017

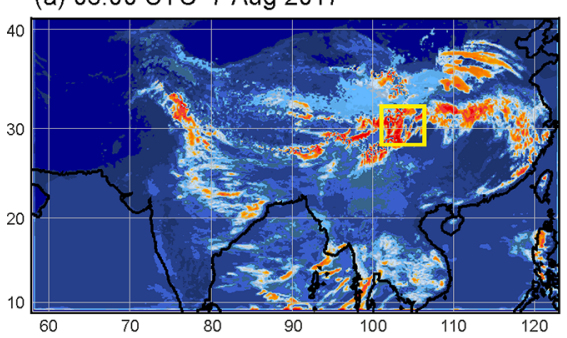

(d) 12:00 UTC 7 Aug 2017

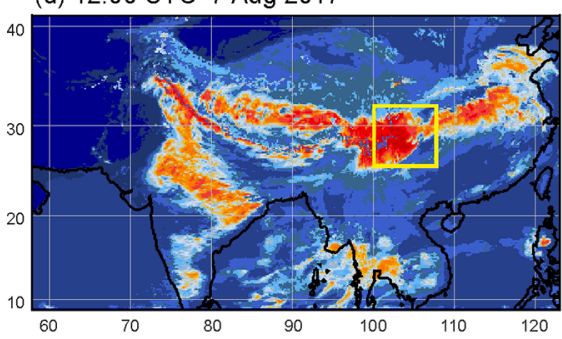

(g) 18:00 UTC 7 Aug 2017

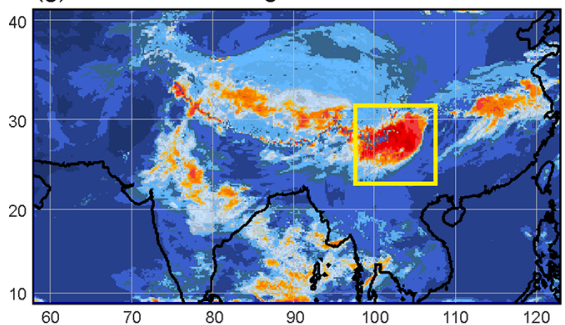

(j) 00:00 UTC 8 Aug 2017

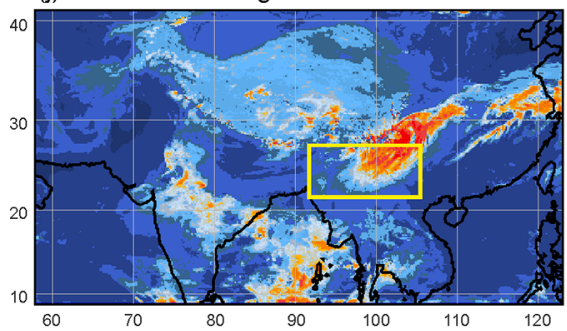

(m) 06:00 UTC 8 Aug 2017

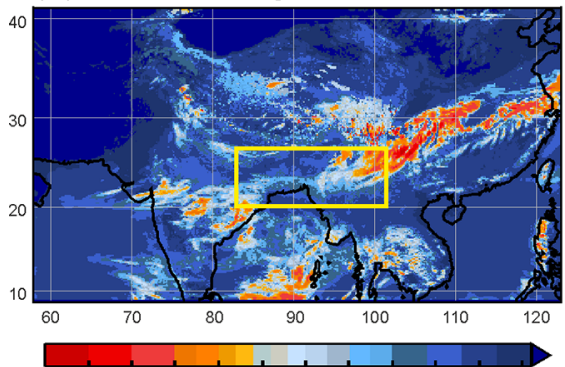

$-80-70-60-50-40-30-20-10 \quad 0 \quad 10 \quad 2030$
$\mathrm{CO}$

(b) 06:00 UTC 7 Aug 2017

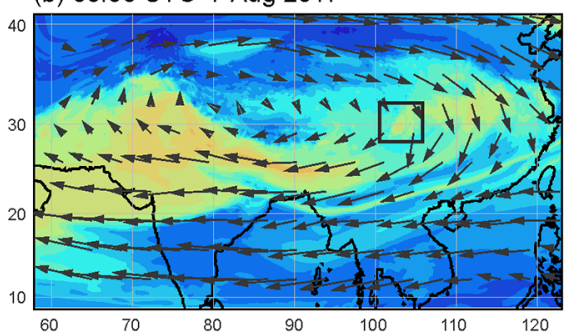

(e) 12:00 UTC 7 Aug 2017

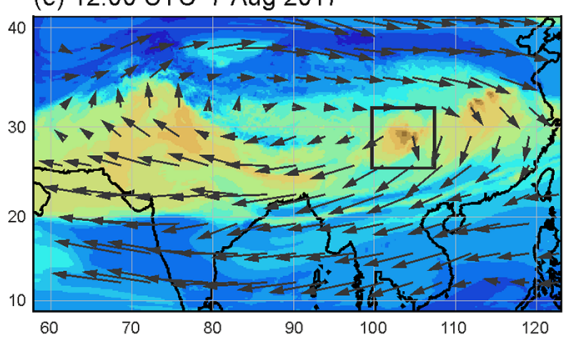

(h) 18:00 UTC 7 Aug 2017

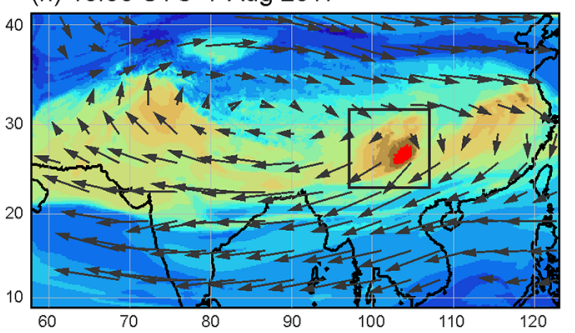

(k) 00:00 UTC 8 Aug 2017

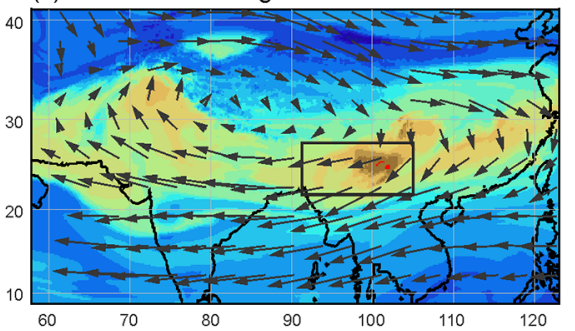

(n) 06:00 UTC 8 Aug 2017

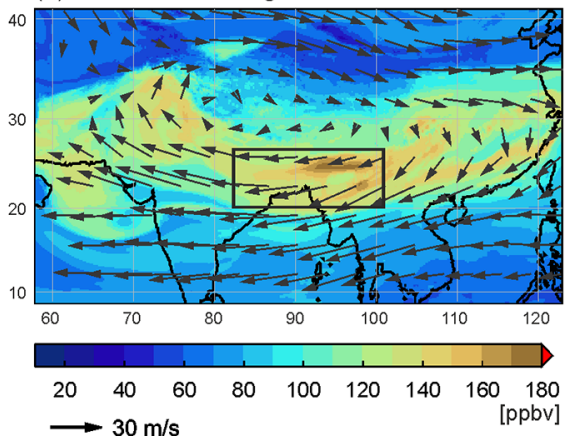

CO (Sichuan contribution)

(c) 06:00 UTC 7 Aug 2017
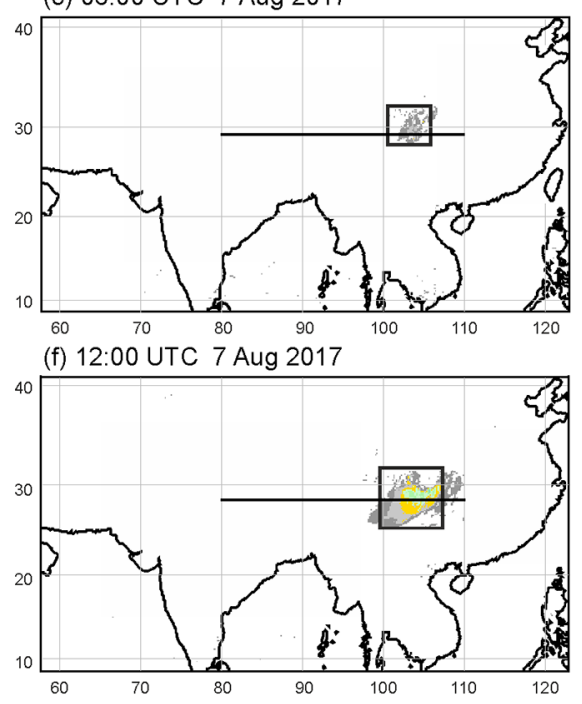

(i) 18:00 UTC 7 Aug 2017

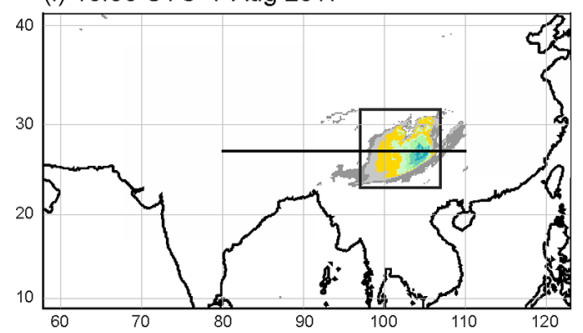

(I) 00:00 UTC 8 Aug 2017

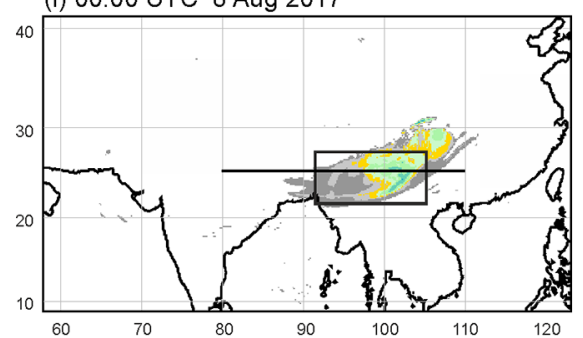

(o) 06:00 UTC 8 Aug 2017

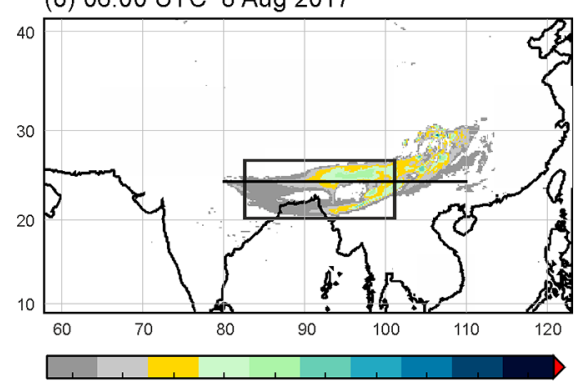

Figure 7. Horizontal map of simulated BT $10.8 \mu \mathrm{m}(\mathrm{K}, \mathbf{a}, \mathbf{d}, \mathbf{g}, \mathbf{j}, \mathbf{m}), \mathrm{CO}$ concentration (ppbv, b, e, h, $\mathbf{k}, \mathbf{n})$, and CO concentration contributed by Sichuan emission $(\%, \mathbf{c}, \mathbf{f}, \mathbf{i}, \mathbf{l}, \mathbf{o})$ at the altitude of $14.8 \mathrm{~km}$ at (a-c) 06:00 UTC, (d-f) 12:00 UTC, (g-i) 18:00 UTC on 7 August, (j-l) 00:00 UTC, and (m-o) 06:00 UTC on 8 August 2017. The area of interest is marked by a black or yellow (for visibility) box. In (c), (f), (i), (l), and (o), the location of the longitude-altitude cross section used in Fig. 8 is marked by a black solid line. 

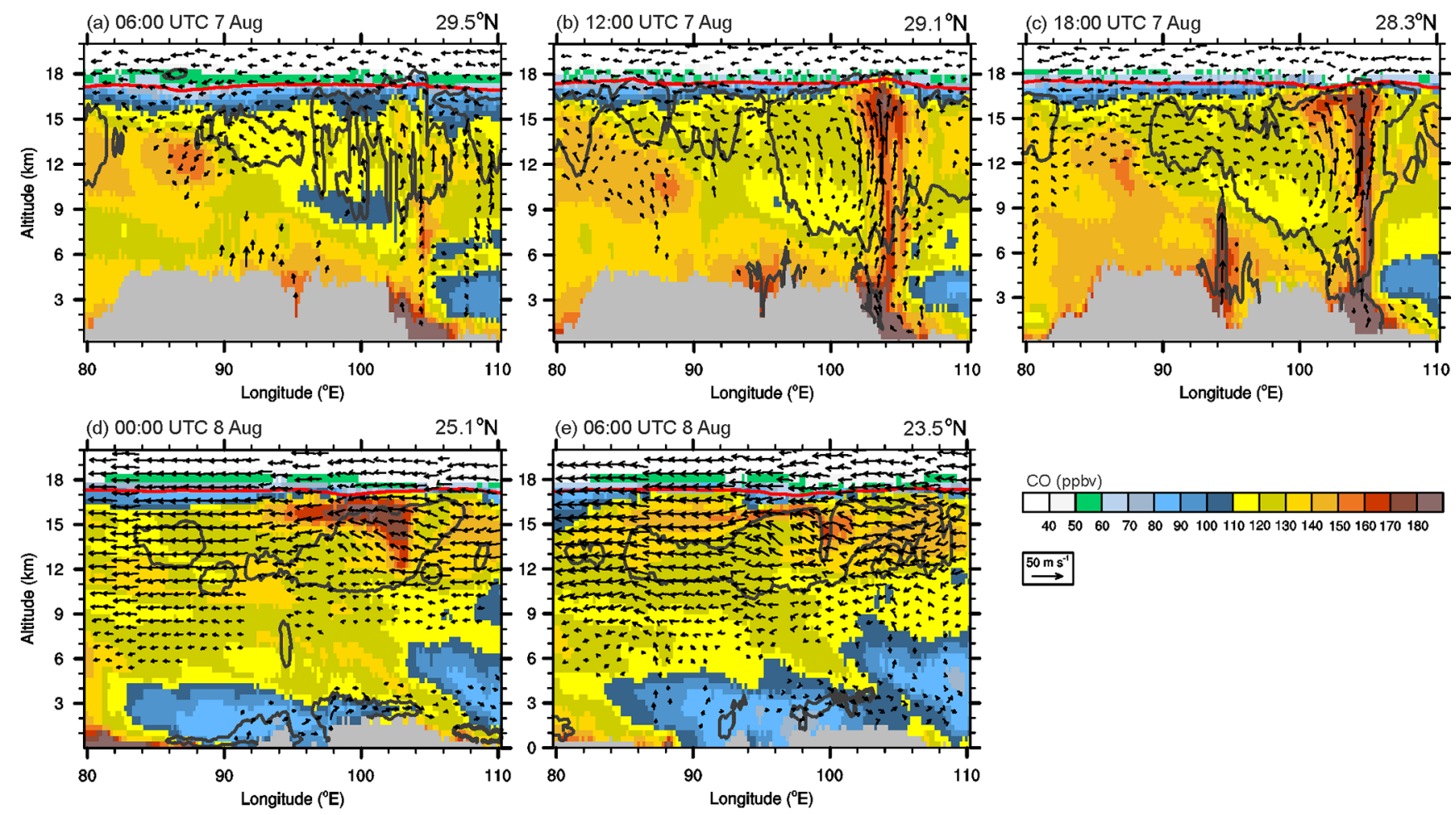

Figure 8. Vertical cross sections of CO concentration (ppbv) from 0.1 to $20 \mathrm{~km}$ altitude at (a) 06:00 UTC, (b) 12:00 UTC, (c) 18:00 UTC on 7 August, (d) 00:00 UTC, and (e) 06:00 UTC on 8 August 2017. The isentropic altitudes of $380 \mathrm{~K}$ is depicted by the red lines. The cloud boundary (mixing ratio of ice content of $10 \mathrm{mg} \mathrm{kg}^{-1}$ ) is contoured by the black line while wind stronger than $5 \mathrm{~m} \mathrm{~s}^{-1}$ is shown by vectors. In each panel, grey areas indicate the topography.

and $\mathrm{CO}$ concentration is uplifted by the intense convective updraughts from the mountain foothills of Sichuan to the tropical tropopause layer (TTL) and the $380 \mathrm{~K}$ isentrope. At 18:00 UTC (Fig. 8c), the horizontal CO concentration divergence is observed in the UT. The CO plume, which was transported to the southwest before 18:00 UTC, is caught by northeasterlies to be further advected westward (Fig. 7k and n). At 00:00 UTC on 8 August, the plume has come out of the convective region with its eastern part still embedded in a high altitude $(11-16 \mathrm{~km})$ cloud and its highest part $(14-16 \mathrm{~km})$ stretched westward by the strong easterlies $(\geq$ $35 \mathrm{~m} \mathrm{~s}^{-1}$ ) (Fig. 8d). At the time of Flight \#7, the CO plume that extends over the $15-17 \mathrm{~km}$ altitude range (Fig. 8e) was diluted with concentrations lower than 170 ppbv (Fig. 7n) and the Sichuan contributions to the total $\mathrm{CO}$ concentration is lower than $10 \%$ (Fig. 7o). In the region south of Kathmandu sampled by the Geophysica aircraft, the Sichuan contribution is reduced to about $2 \%(\sim 5 \mathrm{ppbv})$ at $14.8 \mathrm{~km}$.

The CO concentrations along Flight \#7 resulting from the SIC06 simulation are displayed by a dashed line in Fig. 4c. Depending on the altitude, the impact of Sichuan emissions range from 3 to $10 \mathrm{ppb}$. The most interesting differences between the CNTL and SIC06 occurs between 19200 and $20000 \mathrm{~s}$ when the aircraft first descends from 17 to $14 \mathrm{~km}$ and where it remains for about $4000 \mathrm{~s}$ before ascending to
$18.5 \mathrm{~km}$. During the descent and the ascent, between 15 and $16 \mathrm{~km}$, the measured $\mathrm{CO}$ concentrations are larger by $\sim 10 \mathrm{ppbv}$ than at $14 \mathrm{~km}$, resulting in two small CO peaks. The CNTL simulation reproduces these two peaks fairly well, while they are absent from the SIC06 simulation (dotted line, Fig. 4c). The difference between the two simulations ( $\sim 5 \mathrm{ppbv})$ is about half of the measured $\mathrm{CO}$ concentration. Nevertheless, the coincidence of measured and simulated peaks allows us to attribute to Sichuan emissions the $\sim 3-12$ ppbv increase in $\mathrm{CO}$ concentration in the region of Kathmandu between 15 and $16 \mathrm{~km}$ on 8 August.

To further determine the impact of Sichuan emissions uplifted by the 7 August convective event we have computed the relative difference between the CNTL and SIC06 simulations ( $=[$ CNTL minus SIC06] over [CNTL]) averaged over the AMA domain $\left(20-35^{\circ} \mathrm{N}, 60-120^{\circ} \mathrm{E}\right)$. The evolution of the contribution of Sichuan is displayed in Fig. 9 with the blue bars on top indicating the surface covered by deep convective clouds. The impact in the lowermost layer $(0.1-5 \mathrm{~km})$ starts as soon as the emissions are turned off in the SIC06 simulation and increases steeply until the convection has developed on 7 August 12:00 UTC. Afterwards, the increase slows down in the lower layer because convection transports pollution in the upper layers where the impact increases. The impact remains very limited in the $5-10 \mathrm{~km}$ layer and is more 


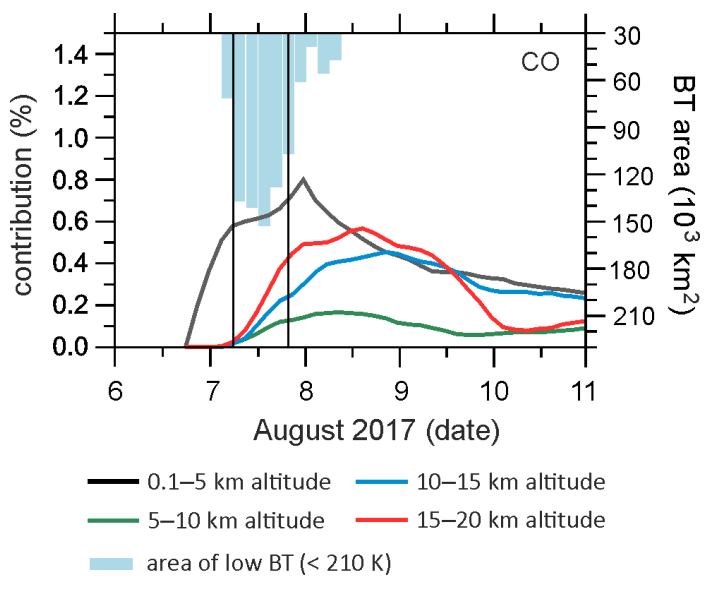

Figure 9. Temporal evolution of the contribution of Sichuan emissions to the $\mathrm{CO}$ concentration of the entire AMA region $\left(60-120^{\circ} \mathrm{E}\right.$, $20-35^{\circ} \mathrm{N}$ ) every $5 \mathrm{~km}$ from 0.1 to $20 \mathrm{~km}$ altitude from 6 to $9 \mathrm{Au}-$ gust 2017 . The areas of low brightness temperature $(210 \mathrm{~K})$ in the Sichuan Basin $\left(101-109^{\circ} \mathrm{E}, 26-33^{\circ} \mathrm{N}\right)$ are displayed by blue bar.

important in the 10-15 and 15-20 km layers because convection detrainment occurs above $10 \mathrm{~km}$. The impact decreases in the $0.1-5 \mathrm{~km}$ layer as soon as the emissions are back to normal in SIC06 (8 August 00:00 UTC) but remains steady $(\sim 0.5 \%)$ until 9 August 12:00 UTC in the two uppermost layers because the $\mathrm{CO}$ convective plume is trapped within the AMA. The sudden release of BL emissions just before the convective activities in the Sichuan Basin is attributed to the rapid increase of $\sim 0.5 \%$ in $\mathrm{CO}$ concentration into the AMA.

The CO plume identified in Figs. 7 and 8 traces pollution emissions from the Sichuan BL into the AMA. In order to gain insight into the impact of Sichuan pollution on the ATAL formation, we looked at the behaviour of simulated primary aerosols emitted by the same sources as $\mathrm{CO}$. The POA (primary organic aerosols) and BC (black carbon) distributions at $14.8 \mathrm{~km}$ for both size modes are displayed in Fig. 10 for 7 August at 18:00 UTC. As expected, the POA coarse particles mode \#2 (accumulation mode; for details about size distribution, see Sect. 2.3) has a much larger contribution to the mass concentration with a maximum of $\sim 5.5 \mu \mathrm{g} \mathrm{m}^{-3}$ over the Sichuan Basin than the small particles mode \#1 (Aitken mode; maxima of $\sim 0.5 \mu \mathrm{g} \mathrm{m}^{-3}$ ). BC peak mass concentrations are about six times lower than POA with the same repartition between mode \#1 and mode \#2.

The longitude-altitude cross sections of the particle mass concentrations (along $28.3^{\circ} \mathrm{N}$ ) displayed in Fig. 11 highlight their convective uplift over the Sichuan Basin. As in Fig. 10, POA are much larger than BC but the main features are identical for both types of particles. Particles of Aitken mode (mode \#1) follow the same transport pathway as $\mathrm{CO}$ (Fig. 8c) with uplift in the convective updraughts up to the $380 \mathrm{~K}$ isentropic level around $104^{\circ} \mathrm{E}$. Relative to CO concentration, their concentrations are largely reduced with only about one-third remaining above $12 \mathrm{~km}$ following scavenging within the convective clouds. Large particles of accumulation mode (mode \#2) enhancement is not even detectable within the convective pipe above $12 \mathrm{~km}$. Indeed large particles are more efficiently scavenged by cloud and rain droplets than small particles. The initial mean aerosol radius of mode $\# 1$ and \#2 are 0.036 and $0.385 \mu \mathrm{m}$, respectively, which is too small to be effectively scavenged by convective precipitation below and in the cloud (Slinn, 1983). This result thus implies that aerosol sizes in both modes within the polluted plume are increased during the uplifting within the cloud by gas-toparticle conversion, condensation of water in the aerosol, and coagulation (Andronache, 2003; Tost et al., 2007; Tulet et al., 2010). Note that mixing of insoluble aerosols such as BC with soluble secondary compounds to become hygroscopic and potentially CCN (cloud condensate nuclei) that could be activated into cloud droplets is not taken into account in the simulation. The topography (top altitudes $\sim 4 \mathrm{~km}$ ) around the Sichuan Basin triggered the continuous deep convective events, which ventilated the large amounts of pollutants, i.e. $\mathrm{CO}, \mathrm{POA}$, and $\mathrm{BC}$, stored at the mountain foothills into the AMA. The simulation results shows us interesting aspects of primary particles of POA and $\mathrm{BC}$ with respect to the development of deep convective clouds; however, it is not supported by measurement and shows the need for future field campaigns deploying instruments that can detect various aerosol particles.

\section{Impact of regional sources on the UTLS composition}

The previous section highlighted the impact of a single strong convective event from a highly polluted region on the composition of the AMA. It can raise the $\mathrm{CO}$ concentration by up to $18 \%$ in the convective area and by up to $10 \%$ over a large region. The impact over the whole AMA reaches a maximum of about half a percent and is largely reduced after a couple of days. In order to determine the impact of emissions from the neighbouring regions to the composition of the AMA during the StratoClim campaign, three additional experiments (Table 3 ) were conducted with emissions turned off over Sichuan (SIC01, 26-33 ${ }^{\circ} \mathrm{N}, 101-109^{\circ} \mathrm{E}$; red box in Fig. 2), over China (CHN01: $20-40^{\circ} \mathrm{N}, 100-122^{\circ} \mathrm{E}$; black box), and over India (IND01, $10-35^{\circ} \mathrm{N}, 70-95^{\circ} \mathrm{E}$; green box) at 00:00 UTC on 1 August until 00:00 UTC on 8 August. Note that the convection activity is identical in all experiments. Figure 12 displays the $10 \mathrm{~d}$ averaged horizontal distributions of $\mathrm{CO}$ concentration at $14.8 \mathrm{~km}$ from the CNTL simulation and the differences between the CNTL and sensitivity experiments SIC01, CHN01, and IND01. The CO concentrations from SIC01, CHN01, and IND01 along the Geophysica flight tracks are displayed in orange, red, and blue in Fig. 4. For the four analysed flights, the local Indian contribution is generally larger than the Sichuan and Chinese remote contributions. This is in agreement with Bucci et al. 

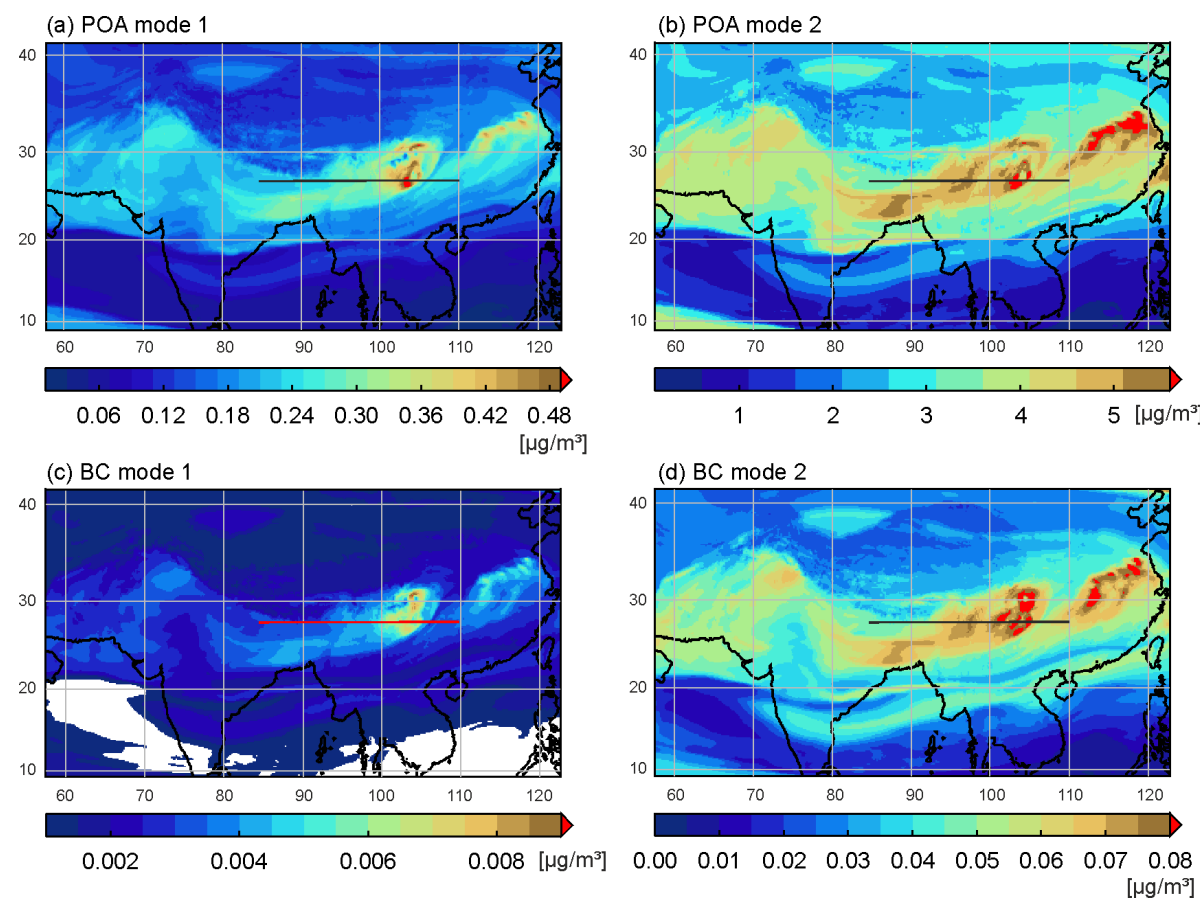

Figure 10. Horizontal map of (a) POA of mode \#1, (b) POA of mode \#2, (c) BC of mode \#1, and (d) BC of mode \#2 at the altitude of 14.8 km at 18:00 UTC on 7 August. The location of vertical cross sections used in Fig. 11 is marked by a black (or red for visibility) solid line in each panel.

(2020) who quantified the convective contribution of different source regions to the $\mathrm{CO}$ concentration along the StratoClim flight tracks using a Lagrangian dispersion model. The Indian larger impact is especially clear at takeoff and landing at altitudes where Chinese air masses are not efficiently transported by the UTLS easterlies.

Flight \#5 (Fig. 4a) took place over the Nepalese region and sampled the $16-20 \mathrm{~km}$ altitude range before the strong convective events in China. Therefore, as documented in Bucci et al. (2020), there is no Chinese contribution during this flight. The local (Indian subcontinent) BL sources contribution since the start of the simulation (1 August 00:00 UTC) to the $\mathrm{CO}$ concentration sampled up to $18 \mathrm{~km}$ is $10-15 \mathrm{ppbv}$ ( $\geq 10 \%$ ). According to the model, recent convection does not provide local fresh pollution above this altitude.

During flight \#6 the aircraft flew back and forth from Kathmandu to the Bay of Bengal coast over Bangladesh (Fig. 1) and remained at a constant altitude of $\sim 17 \mathrm{~km}$ (Fig. 4). During the whole flight at $17 \mathrm{~km}$, the Chinese contribution is larger than the Indian contribution, which remains weak or null. According to Bucci et al. (2020), the two largest CO concentration peaks at $\sim 32500$ and $\sim 35500$ s result from Sichuan BL air masses convectively uplifted $2 \mathrm{~d}$ before. As mentioned in Sect. 3.2, the Meso-NH model is not able to capture these two peaks but rather smooth $\mathrm{CO}$ enhancements. The CHN01 sensitivity simulation highlights the Chinese origin of enhanced CO concentration between 32000 and 37000 s, similarly to Fig. 7 in Bucci et al. (2020). The SIC01 simulation suggests more specifically that the origin of enhanced $\mathrm{CO}$ concentration is not Sichuan contrarily to Bucci et al. (2020). The model missed the convective event responsible for these particular peaks and is therefore not able to reproduce them. Bucci et al. (2020) pointed to air masses from the Southeast Asian peninsula and South China recently uplifted to lower levels $(13 \mathrm{~km})$ for the highest $\mathrm{CO}$ concentration peak corresponding to the aircraft dive at $15 \mathrm{~km}$. Our sensitivity simulations confirm the Chinese (excluding Sichuan) contribution and the almost zero Indian contribution to this peak. The differences could be partly induced by the differences in emission data (i.e. MIX vs. MACCity) and the slightly different cloud location in the observations vs. the model.

Flight \#7 has already been discussed in terms of the impact of the 7 August strong convective event in Sichuan. In agreement with Fig. 10 in Bucci et al. (2020), we find an important Chinese contribution all along this flight. As the $\mathrm{CO}$ concentration from CHNO1 and SIC01 are almost similar, this Chinese contribution mostly originates from Sichuan.

Flight \#8 on 10 August was intended to sample the outflow of an intense convective system that had developed over the Ganges valley. During the first leg of the flight, the aircraft flew in the inner core of the AMA around the altitude of the tropopause $(85-90 \mathrm{hPa})$, sampling old air that had been convectively injected into the UTLS mostly more than $10 \mathrm{~d}$ ago (Bucci et al., 2020). This means that the Meso-NH sensitivity simulations cannot fully determine the source apportion- 

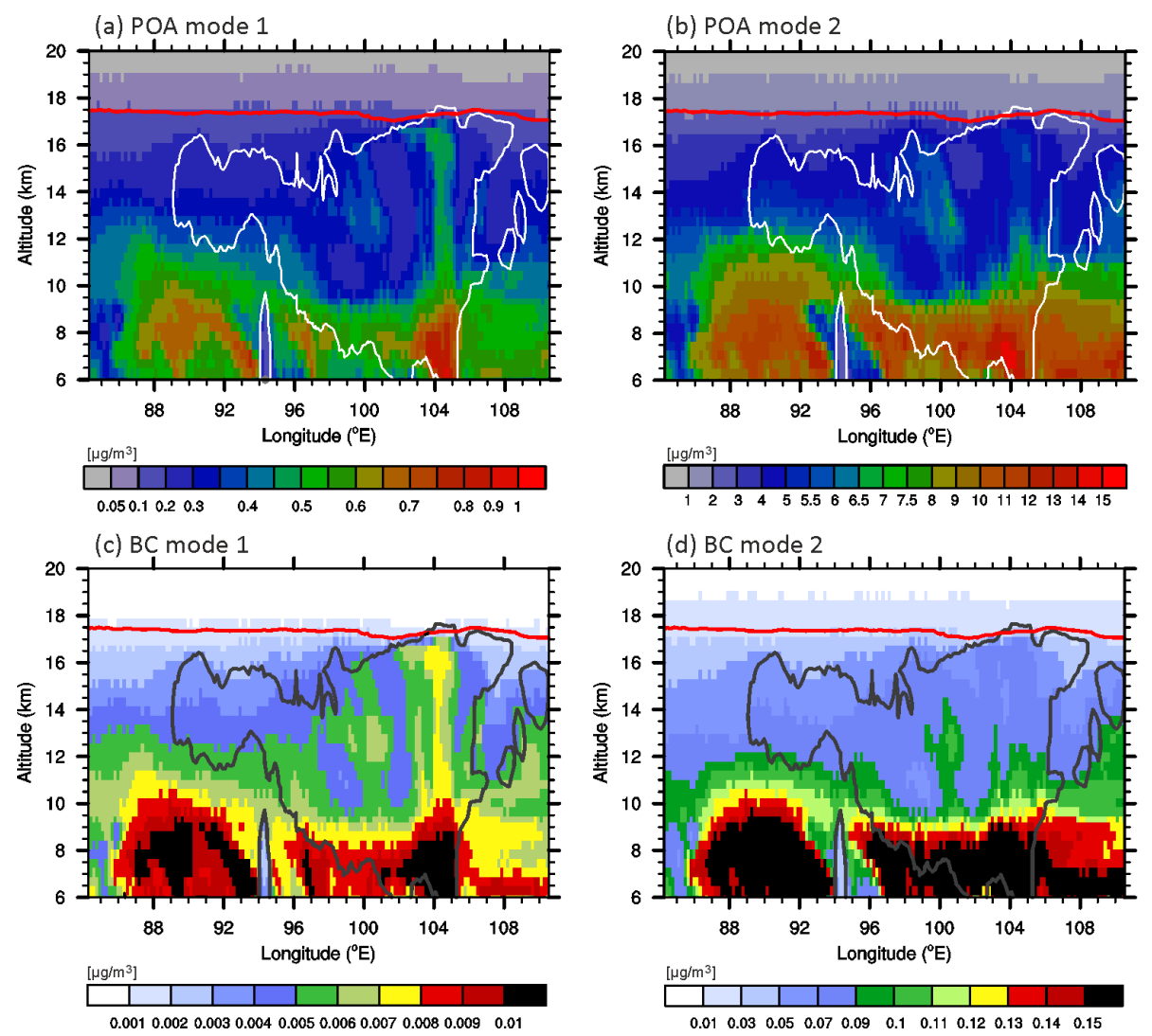

Figure 11. Vertical cross sections of (a) POA of mode \#1, (b) POA of mode \#2, (c) BC of mode \#1, and (d) BC of mode \#2 from 6 to $20 \mathrm{~km}$ altitude along the $x$ axis of the area of interest at 18:00 UTC on 7 August. The isentropic altitudes of $380 \mathrm{~K}$ is depicted by the red lines. The cloud boundary (mixing ratio of ice content of $10 \mathrm{mg} \mathrm{kg}^{-1}$ ) is contoured by the black or white line (for visibility).

ment for CO concentration. Nevertheless, between 35000 and $38000 \mathrm{~s}$, about $10 \mathrm{ppbv} \mathrm{CO}$ can be attributed to BL air masses from both the Indian and Chinese domain uplifted after 1 August 00:00 UTC. The Chinese and Indian contributions are also detected for this period of the flight in Bucci et al. (2020). After $38200 \mathrm{~s}$ and during the stratospheric part of the flight (after $40200 \mathrm{~s}$ ) and before landing, the Chinese and Indian contributions from less than $10 \mathrm{~d}$ before are negligible. The analysis of the $\mathrm{CO}$ concentration from our Meso-NH simulations along the StratoClim flights in light of the study of Bucci et al. (2020) have allowed us to further validate the model. It is able to correctly reproduce the convective uplift and transport pathways of pollution from the main Asian regions to the AMA even if some convective events resulting in UTLS CO peaks were missing.

Interestingly, between 42500 and $43000 \mathrm{~s}$ in Flight \#8 and between 22600 and $22800 \mathrm{~s}$ in Flight \#7 CO concentration from the CHNO1 simulation is lower and in better agreement with observed $\mathrm{CO}$, which remains close to stratospheric background, than CO from the CNTL simulation. This implies that the contribution of Chinese pollution to the lower stratosphere is slightly overestimated by the model and that the latest contribution of BL pollution to this altitude probably dates back several weeks.

Looking at the UT CO distributions from our simulations allows us to have a broader view of the average impact of the source regions. Observed and simulated clouds are globally coincident during the 1-10 August period. The model slightly underestimates their extension and intensity. CO distribution from the CNTL run (Fig. 12a) is characterized by two large regions of high $\mathrm{CO}$ concentration $(\geq$ $120 \mathrm{ppbv}$ ): the first one at the foot of the Himalayas encompasses large parts of Pakistan, northern India, Nepal, and Bangladesh $\left(20-30^{\circ} \mathrm{N}, 70-95^{\circ} \mathrm{E}\right)$ and the second one large parts of central China $\left(100-120^{\circ} \mathrm{E}, 20-30^{\circ} \mathrm{N}\right)$. The CO distribution of CNTL minus CHN01 (Fig. 12b) highlights that about $20 \%(\sim 25 \mathrm{ppbv})$ of $\mathrm{CO}$ concentration over central China comes directly from China. Otherwise, the uplifted Chinese emissions follow the easterlies and mostly affect the southern part of the AMA from southern China to the Arabian Sea with 12-15 ppbv contributions. The emissions from the Sichuan Basin alone account for about $7 \%(\sim 10 \mathrm{ppbv})$ of $\mathrm{CO}$ over central China and also follow the easterlies but north of the main Chinese plume (Fig. 12c). The $10 \mathrm{~d}$ average contribution of Chinese emission to the whole AMA 
(a) CNTL $10 \mathrm{~d}$ average $\mathrm{CO}$

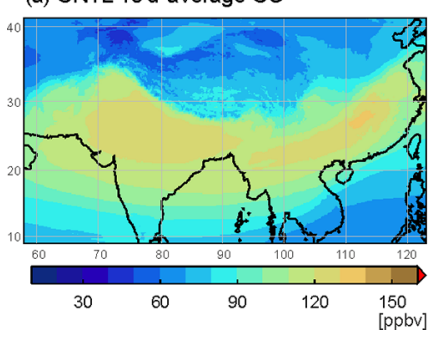

(b) CNTL minus CHNO1

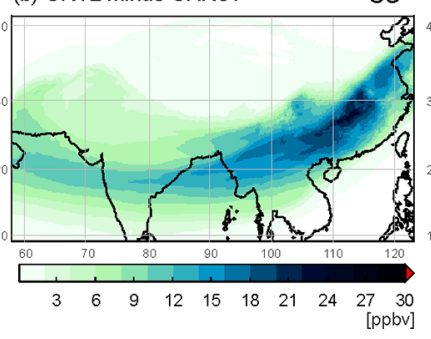

(c) CNTL minus SIC01

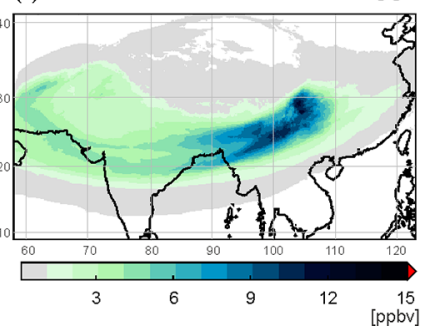

(d) CNTL minus IND01 CO

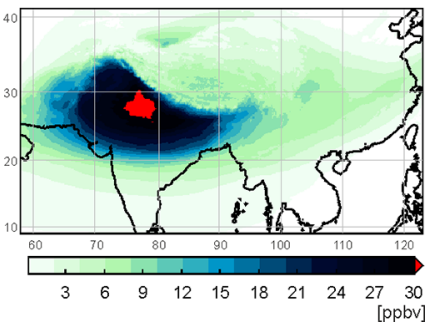

Figure 12. $10 \mathrm{~d}$ averaged chemical components of $\mathrm{CO}$ concentration (ppbv) at the altitude of $14.8 \mathrm{~km}$ from 1 to 10 August 2017 produced by (a) CNTL, (b) CNTL minus CHN01, (c) CNTL minus SIC01, and (d) CNTL minus IND01.

is $6.9 \%(8.0 \mathrm{ppbv})$ in the $10-15 \mathrm{~km}$ layer and reaches $3.3 \%$ (1.9 ppbv) in the $15-20 \mathrm{~km}$ layer. These values are smaller than the contribution of East Asia (10 ppbv) computed by Barret et al. (2016) using simulations from the GEOS-Chem model for the month of August 2009. Note the different timescale used in the studies ( $10 \mathrm{~d}$ vs. 1 month) since AMA composition varies with a typical period of two weeks (cf. Bucci et al., 2020) and even a month and a season.

Indian emissions (Fig. 12d) impact the whole AMA from the Arabian sea to the Pacific but most notably its central region west and south of the Himalayas (Bangladesh, northern India, Pakistan, Afghanistan) with a contribution of $20 \%-$ $25 \%$ (25-30 ppbv) to the CO. Averaged over 1-10 August, the Indian domain contributed $10.9 \%$ and $6.2 \%$ (12.8 and $3.7 \mathrm{ppbv}$ ) $\mathrm{CO}$ concentration in the layers from 10 to $15 \mathrm{~km}$ and from 15 to $20 \mathrm{~km}$, respectively. Barret et al. (2016) found a larger contribution of $24 \mathrm{ppbv}$ for their South Asian domain. As in Barret et al. (2016) we find that the Indian (South Asian) contribution is about 1.6 times that of the Chinese (East Asian) contribution to $\mathrm{CO}$ in the AMA.

\section{Summary}

This paper focuses on the emission sources and pathways of pollution from the BL to the AMA during the StratoClim campaign period. We performed cloud-chemistry simulations with the Meso-NH model with $15 \mathrm{~km}$ horizontal and 100 to $450 \mathrm{~m}$ vertical resolutions. To validate the simulated clouds, we used a combination of the IR window data from the MSG-SEVIRI and Himawari-AHI geostationary instruments. The $\mathrm{CO}$ and $\mathrm{O}_{3}$ distributions were compared with in situ airborne observations from the StratoClim campaign in the TTL region and from the IAGOS programme in the UT. The comparison of the IR window BT demonstrates the ability of the model to reproduce the deep convective clouds over the whole Asian region but more specifically the intense events that took place over the Sichuan Basin on 7 August 2017. Comparisons with StratoClim and IAGOS measurements show that Meso-NH correctly reproduces the variations of both $\mathrm{CO}$ and $\mathrm{O}_{3}$ concentration in the Asian UTLS from 11 to $21 \mathrm{~km}$. Nevertheless, $\mathrm{CO}$ concentrations are reg- ularly overestimated by $20 \mathrm{ppbv}$ in the TTL and even by $40 \mathrm{ppbv}$ in the troposphere. This gap could be influenced by the selected emission and initial atmospheric chemistry data (i.e. MOZART) in this study. $\mathrm{O}_{3}$ is also overestimated by $\sim 20 \mathrm{ppbv}$ in the troposphere and TTL, up to $100 \mathrm{ppbv}$ in the extratropical UTLS, and in the AMA close to the $380 \mathrm{~K}$ isentropic level (17.8 km).

During the StratoClim period, exceptionally strong convection occurred in the Sichuan Basin at the Tibetan plateau foothills (east of $90^{\circ} \mathrm{E}$ ) with clouds reaching the tropopause over large areas and overshooting the local tropopause. The SIC06 simulation was dedicated to the characterization of the transport pathway of BL pollution from the Sichuan to the UTLS and on the impact of the 7 August convective event on the composition of the AMA. The results show that BL CO concentration convectively uplifted up to $18 \mathrm{~km}$ $(380 \mathrm{~K}$ isentropic level at $17.8 \mathrm{~km})$ contributes more than $15 \%$ ( 25 ppbv) to the $\mathrm{CO}$ within the convective core where it reaches $195 \mathrm{ppbv}$. The $\mathrm{CO}$ plume is further transported westward by the strong northeasterlies and easterlies on the edge of the AMA and reaches the region south of Kathmandu at the time of StratoClim Flight \#7. The aircraft mostly flew above the most impacted altitudes range $(15-17 \mathrm{~km})$ and the plume had been largely diluted when it reached the flight track. Nevertheless, the difference between the CNTL and the SIC06 simulations demonstrates that two peaks corresponding to $10 \mathrm{ppbv} \mathrm{CO}$ anomalies detected during flight \#7 between 14 and $16 \mathrm{~km}$ most likely result from the Sichuan pollution plume. Over the whole AMA, the impact of the 7 August Sichuan convective event contributed to $\sim 0.5 \%$ in the layer between 10 and $20 \mathrm{~km}$ over $2 \mathrm{~d}$. The Meso-NH simulation also documents the uplift of carbonaceous primary particles (BC and POA) to the tropopause over Sichuan and their further transport westward. Interestingly, accumulation mode particles (initial mean radius of $0.385 \mu \mathrm{m}$; standard deviation of 1.29) are increased during the uplifting within the cloud and are more scavenged within the convective clouds, but their contribution remains much more important to the mass concentration in the AMA.

Dedicated sensitivity simulations showed that the Indian (IND01 run) and Chinese (CHN01 run) domains mostly im- 
pact the AMA locally with contributions of 25 to $30 \mathrm{ppbv}$. The Chinese contribution is advected westward at the southern edge of the AMA by the easterlies, while the Indian contribution remains within the core region of the AMA. The Chinese and Indian contributions to the CO simulated along the StratoClim flight tracks have been compared to results from Lagrangian dispersion modelling (Bucci et al., 2020). Despite some important methodological differences, we nonetheless found good general agreement with some $\mathrm{CO}$ concentration peaks originating from recent convection (from Southeast Asia and Sichuan) not captured by Meso$\mathrm{NH}$. For the whole AMA averaged over $10 \mathrm{~d}$, the Indian contribution (11\%) is about 1.6 times larger than the Chinese contribution (7\%). The Chinese contribution is mostly from southern China where monsoon convection is the largest (Bucci et al., 2020). Nevertheless, the SIC01 simulation highlights that Sichuan represented an important part (35\%) of the Chinese contribution as a result of the strong convective events that occurred in this region during the StratoClim campaign. Comparisons with Barret et al. (2016) have shown that smaller contributions are derived during the period of 110 August 2017 compared to the month of August 2009. Further studies will focus on the formation and transport pathways of particles that form the ATAL and on simulations at higher horizontal resolution $(<5 \mathrm{~km})$, which will resolve deep convection. Further, it would be interesting to investigate the model's ability to reproduce the aerosol number concentration via convective overshoots during this season.

Data availability. StratoClim data will be freely available from the https://halo-db.pa.op.dlr.de/mission/101 (last access: 1 March 2021) (DLR, 2021) database from the end of June 2020; in the meantime they will be available upon request to the authors. Meso-NH output data are available from Eric. L. Flochmoën upon request. The satellite data and the emission data are freely provided by the AERIS data centres (https://aeris-data.fr, last access: 1 March 2021) (SEDOO, 2021)).

Author contributions. KOL and BB designed the numerical simulation and analyses. ELF, BB, KOL, and PT performed numerical simulations. ML contributed to the Meso-NH configuration for the chemistry part. MVH, CK, FR, and AU provided the aircraft instrumental data, and BL and SB provided the satellite data. KOL prepared the manuscript with contributions from all co-authors.

Competing interests. The authors declare that they have no conflict of interest.

Special issue statement. This article is part of the special issue "StratoClim stratospheric and upper tropospheric processes for better climate predictions (ACP/AMT inter-journal SI)". It is not associated with a conference.
Acknowledgements. The authors thank Céline Marie (Laboratoire d'Aérologie) for her insightful suggestions. IAGOS data were created with support from the European Commission, national agencies in Germany (BMBF), France (MESR), and the UK (NERC), and the IAGOS member institutions (https://www.iagos. org/organisation/members/, last access: 1 March 2021). The participating airlines (Lufthansa, Air France, Austrian, China Airlines, Iberia, Cathay Pacific, Air Namibia, and Sabena) supported IAGOS by carrying the measurement equipment free of charge since 1994. The data are available at http://www.iagos.fr (last access: 1 March 2021) thanks to additional support from AERIS. Meteorological analysis data are provided by the European Centre for Medium-Range Weather Forecasts.

Financial support. This work was supported by the French ANR TTL-Xing ANR-17-CE01-0015 project and the StratoClim project by the European Community's Seventh Framework Programme (FP7/2007-2013) under grant agreement no. 603557. We also thank CEFIPRA for support through grant 5607-1.

Review statement. This paper was edited by Gabriele Stiller and reviewed by three anonymous referees.

\section{References}

Andronache, C.: Estimated variability of below-cloud aerosol removal by rainfall for observed aerosol size distributions, Atmos. Chem. Phys., 3, 131-143, https://doi.org/10.5194/acp-3131-2003, 2003.

Barret, B., Ricaud, P., Mari, C., Attié, J.-L., Bousserez, N., Josse, B., Le Flochmoën, E., Livesey, N. J., Massart, S., Peuch, V.H., Piacentini, A., Sauvage, B., Thouret, V., and Cammas, J.P.: Transport pathways of $\mathrm{CO}$ in the African upper troposphere during the monsoon season: a study based upon the assimilation of spaceborne observations, Atmos. Chem. Phys., 8, 3231-3246, https://doi.org/10.5194/acp-8-3231-2008, 2008.

Barret, B., Sauvage, B., Bennouna, Y., and Le Flochmoen, E.: Upper-tropospheric $\mathrm{CO}$ and $\mathrm{O}_{3}$ budget during the Asian summer monsoon, Atmos. Chem. Phys., 16, 9129-9147, https://doi.org/10.5194/acp-16-9129-2016, 2016.

Bechtold, P., Bazile, E., Guichard, F., Mascart, P., and Richard, E.: A mass-flow convection scheme for regional and global models, Q. J. Roy. Meteorol. Soc. 127, 869-886, https://doi.org/10.1002/qj.49712757309, 2001.

Bian, J., Pan, L. L., Paulik, L., Vomel, H., Chen, H., and Lu, D.: In situ water vapor and ozone measurements in Lhasa and Kunming during the Asian summer monsoon, Geophys. Res. Lett., 39, L19808, https://doi.org/10.1029/2012GL052996, 2012.

Bian, J., Li, D., Bai, Z., Li, Q., Lyu, D., and Zhou, X.: Transport of Asian surface pollutants to the global stratosphere from the Tibetan Plateau region during the Asian summer monsoon, Natl. Sci. Rev., 7, 516-533, https://doi.org/10.1093/nsr/nwaa005, 2020.

Bougeault, P., and Lacarrère, P.: Parameterization of orographyinduced turbulence in a meso-beta-scale model, Mon. 
Weather Rev., 117, 1872-1890, https://doi.org/10.1175/15200493(1989)117<1872:POOITI>2.0.CO;2, 1989.

Bresson, E., Ducrocq, V., Nuissier, O., Ricard, D., and De SaintAubin, C.: Idealized numerical simulations of quasi stationary convective systems over the Northwestern Mediterranean comple terrain, Q. J. Roy. Meteorol. Soc., 138, 1751-1763, https://doi.org/10.1002/qj.1911, 2012.

Bucci, S., Legras, B., Sellitto, P., D’Amato, F., Viciani, S., Montori, A., Chiarugi, A., Ravegnani, F., Ulanovsky, A., Cairo, F., and Stroh, F.: Deep-convective influence on the upper tropospherelower stratosphere composition in the Asian monsoon anticyclone region: 2017 StratoClim campaign results, Atmos. Chem. Phys., 20, 12193-12210, https://doi.org/10.5194/acp-20-121932020, 2020.

Chaboureau, J.-P., Söhne, N., Pinty, J.-P., Meirold-Mautner, I., Defer, E., Prigent, C., Pardo, J. R., Mech, M., and Crewell, S.: A midlatitude precipitating cloud database validated with satellite observations, J. Appl. Meteorol. Clim., 47, 1337-1353, https://doi.org/10.1175/2007JAMC1731.1, 2008.

Colella, P. and Woodward, P. R.: The piecewise parabolic method (PPM) for gas dynamical simulations, J. Comput. Phys., 54, 174-201, https://doi.org/10.1016/0021-9991(84)90143-8, 1984.

Cuxart, J., Bougeault, P., and Redelsperger, J. L.: A turbulence scheme allowing for mesoscale and large-eddy simulations, Q. J. Roy. Meteorol. Soc., 126, 1-30, https://doi.org/10.1002/qj.49712656202, 2000.

Dickerson, R. R. and Delany, A. C.: Modification of a commercial gas filter correlation CO detector for enhanced sensitivity, J. Atmos. Ocean. Tech., 5, 424-431, 1987.

Diehl, T., Heil, A., Chin, M., Pan, X., Streets, D., Schultz, M., and Kinne, S.: Anthropogenic, biomass burning, and volcanic emissions of black carbon, organic carbon, and $\mathrm{SO}_{2}$ from 1980 to 2010 for hindcast model experiments, Atmos. Chem. Phys. Discuss., 12, 24895-24954, https://doi.org/10.5194/acpd-1224895-2012, 2012.

DLR - Deutsches Zentrum für Luft- und Raumfahrt e.V.: HALODB, available at: https://halo-db.pa.op.dlr.de/mission/101, last access: 1 March 2021.

Ducrocq, V., Nuissier, O., Ricard, D., Lebeaupin, C., and Thouvenin, R.: A numerical study of three catastrophic precipitating events over southern France, Mesoscale triggering and stationary factors, Q. J. Roy. Meteorol. Soc., 134, 131-145, 2008.

Emmons, L. K., Walters, S., Hess, P. G., Lamarque, J.-F., Pfister, G. G., Fillmore, D., Granier, C., Guenther, A., Kinnison, D., Laepple, T., Orlando, J., Tie, X., Tyndall, G., Wiedinmyer, C., Baughcum, S. L., and Kloster, S.: Description and evaluation of the Model for Ozone and Related chemical Tracers, version 4 (MOZART-4), Geosci. Model Dev., 3, 43-67, https://doi.org/10.5194/gmd-3-43-2010, 2010.

Fadnavis, S., Semeniuk, K., Pozzoli, L., Schultz, M. G., Ghude, S. D., Das, S., and Kakatkar, R.: Transport of aerosols into the UTLS and their impact on the Asian monsoon region as seen in a global model simulation, Atmos. Chem. Phys., 13, 8771-8786, https://doi.org/10.5194/acp-13-8771-2013, 2013.

Gal-Chen, T. and Somerville, R. C. J.: On the use of a coordinate transformation for the solution of the Navier-Stokes equations, J. Comput. Phys., 17, 209-228, https://doi.org/10.1016/00219991(75)90037-6, 1975.
Granier, C., Bessagnet, B., Bond, T., D’Angiola, A., van der Gon, H. D., Frost, G. J., Heil, A., Kaiser, J. W., Kinne, S., and Klimont, Z.: Evolution of anthropogenic and biomass burning emissions of air pollutants at global and regional scales during the 1980-2010 period, Climatic Change, 109, 163-190, https://doi.org/10.1007/s10584-011-0154-1, 2011.

Grell, G. A. and Freitas, S. R.: A scale and aerosol aware stochastic convective parameterization for weather and air quality modeling, Atmos. Chem. Phys., 14, 5233-5250, https://doi.org/10.5194/acp-14-5233-2014, 2014.

Griffin, R. J., Dabdub, D., and Seinfeld, J. H.: Secondary organic aerosol, 1, Atmospheric chemical mechanism for production of molecular constituents, J. Geophys. Res., 107, 4332, https://doi.org/10.1029/2001JD000541, 2002.

Griffin, R. J., Nguyen, K., Dabdub, D., and Seinfeld, J. H.: A coupled hydrophobic-hydrophilic model for predicting secondary organic aerosols formation, J. Atmos. Chem., 44, 171-190, https://doi.org/10.1023/a:1022436813699, 2003.

Griffin, R. J., Dabdub, D., and Seinfeld, J. H.: Development and initial evaluation of a dynamic species-resolved model for gas phase chemistry and size-resolved gas/particle partitioning associated with secondary organic aerosols formation, J. Geophys. Res.Atmos., 110, D05304, https://doi.org/10.1029/2004JD005219, 2005.

Gu, Y., Liao, H., and Bian, J.: Summertime nitrate aerosol in the upper troposphere and lower stratosphere over the Tibetan Plateau and the South Asian summer monsoon region, Atmos. Chem. Phys., 16, 6641-6663, https://doi.org/10.5194/acp-166641-2016, 2016.

Guenther, A., Karl, T., Harley, P., Wiedinmyer, C., Palmer, P. I., and Geron, C.: Estimates of global terrestrial isoprene emissions using MEGAN (Model of Emissions of Gases and Aerosols from Nature), Atmos. Chem. Phys., 6, 3181-3210, https://doi.org/10.5194/acp-6-3181-2006, 2006.

Highwood, E. J. and Hoskins, B. J.: The tropical tropopause, Q. J. Roy. Meteorol. Soc., 124, 1579-1604, https://doi.org/10.1002/qj.49712454911, 1998.

Hoskins, B. J. and Rodwell, M. J.: A model of the Asian summer monsoon, I, The global scale, J. Atmos. Sci., 52, 1329-1340, https://doi.org/10.1175/15200469(1995)052<1329:AMOTAS>2.0.CO;2, 1995.

Kloss, C., Tan, V., Leen, J. B., Madsen, G. L., Gardner, A., Du, X., Kulessa, T., Schillings, J., Schneider, H., Schrade, S., Qiu, C., and von Hobe, M.: Airborne Mid-Infrared Cavity enhanced Absorption spectrometer (AMICA), Atmos. Meas. Tech. Discuss. [preprint], https://doi.org/10.5194/amt-2021-28, in review, 2021.

Lac, C., Chaboureau, J.-P., Masson, V., Pinty, J.-P., Tulet, P., Escobar, J., Leriche, M., Barthe, C., Aouizerats, B., Augros, C., Aumond, P., Auguste, F., Bechtold, P., Berthet, S., Bielli, S., Bosseur, F., Caumont, O., Cohard, J.-M., Colin, J., Couvreux, F., Cuxart, J., Delautier, G., Dauhut, T., Ducrocq, V., Filippi, J.B., Gazen, D., Geoffroy, O., Gheusi, F., Honnert, R., Lafore, J.-P., Lebeaupin Brossier, C., Libois, Q., Lunet, T., Mari, C., Maric, T., Mascart, P., Mogé, M., Molinié, G., Nuissier, O., Pantillon, F., Peyrillé, P., Pergaud, J., Perraud, E., Pianezze, J., Redelsperger, J.-L., Ricard, D., Richard, E., Riette, S., Rodier, Q., Schoetter, R., Seyfried, L., Stein, J., Suhre, K., Taufour, M., Thouron, O., Turner, S., Verrelle, A., Vié, B., Visentin, F., Vion- 
net, V., and Wautelet, P.: Overview of the Meso-NH model version 5.4 and its applications, Geosci. Model Dev., 11, 19291969, https://doi.org/10.5194/gmd-11-1929-2018, 2018.

Lamarque, J.-F., Bond, T. C., Eyring, V., Granier, C., Heil, A., Klimont, Z., Lee, D., Liousse, C., Mieville, A., Owen, B., Schultz, M. G., Shindell, D., Smith, S. J., Stehfest, E., Van Aardenne, J., Cooper, O. R., Kainuma, M., Mahowald, N., McConnell, J. R., Naik, V., Riahi, K., and van Vuuren, D. P.: Historical (1850-2000) gridded anthropogenic and biomass burning emissions of reactive gases and aerosols: methodology and application, Atmos. Chem. Phys., 10, 7017-7039, https://doi.org/10.5194/acp-10-7017-2010, 2010.

Lee, K. O., Flamant, C., Ducrocq, V., Duffourg, F., Fourrié, N., and Davolio, S.: Convective initiation and maintenance processes of two back-building mesoscale convective systems leading to heavy precipitation events in Southern Italy during HyMeX IOP 13, Q. J. Roy. Meteorol. Soc., 142, 2623-2635, https://doi.org/10.1002/qj.2978, 2016.

Lee, K.-O., Flamant, C., Duffourg, F., Ducrocq, V., and Chaboureau, J.-P.: Impact of upstream moisture structure on a back-building convective precipitation system in south-eastern France during HyMeX IOP13, Atmos. Chem. Phys., 18, 1684516862, https://doi.org/10.5194/acp-18-16845-2018, 2018.

Lee, K.-O., Dauhut, T., Chaboureau, J.-P., Khaykin, S., Krämer, M., and Rolf, C.: Convective hydration in the tropical tropopause layer during the StratoClim aircraft campaign: pathway of an observed hydration patch, Atmos. Chem. Phys., 19, 11803-11820, https://doi.org/10.5194/acp-19-11803-2019, 2019.

Li, Q., Jiang, J. H., Wu, D. L., Read, W. G., Livesey, N. J., Waters, J. W., Zhang, Y., Wang, B., Filipiak, M. J., Davis, C. P., Turquety, S., Wu, S., Park, R. J., Yantosca, R. M., and Jacob, D. J.: Convective outflow of south Asian pollution: A global CTM simulation compared with EOS MLS observations, Geophys. Res. Lett., 32, L14826, https://doi.org/10.1029/2005GL022762, 2005.

Li, Y., Pickering, K. E., Barth, M. C., Bela, M. M., Cummings, K. A., and Allen, D. J.: Evaluation of parameterized convective transport of trace gases in simulation of storms observed during the DC3 field campaign, J. Geophys. Res.-Atmos., 123, 1123811261, https://doi.org/10.1029/2018JD028779, 2018.

Markowski, P. and Richardson, Y.: Mesoscale Meteorology in Midlatitudes, Wiley-Blackwell, Oxford, UK, 206-209, 2010.

Mason, R. and Anderson, C.: The development and decay of the 100-MB. Summertime anticyclone over southern Asia, Mon. Weather Rev., 1, 3-12, https://doi.org/10.1175/15200493(1963)091<0003:TDADOT>2.3.CO;2, 1963.

Masson, V., Le Moigne, P., Martin, E., Faroux, S., Alias, A., Alkama, R., Belamari, S., Barbu, A., Boone, A., Bouyssel, F., Brousseau, P., Brun, E., Calvet, J.-C., Carrer, D., Decharme, B., Delire, C., Donier, S., Essaouini, K., Gibelin, A.-L., Giordani, H., Habets, F., Jidane, M., Kerdraon, G., Kourzeneva, E., Lafaysse, M., Lafont, S., Lebeaupin Brossier, C., Lemonsu, A., Mahfouf, J.-F., Marguinaud, P., Mokhtari, M., Morin, S., Pigeon, G., Salgado, R., Seity, Y., Taillefer, F., Tanguy, G., Tulet, P., Vincendon, B., Vionnet, V., and Voldoire, A.: The SURFEXv7.2 land and ocean surface platform for coupled or offline simulation of earth surface variables and fluxes, Geosci. Model Dev., 6, 929-960, https://doi.org/10.5194/gmd-6-929-2013, 2013.
Metzger, S., Dentener, F., Pandis, S., and Lelieveld, J.: Gas/aerosols partitioning: 1. A computationally efficient model, J. Geophys Res., 107, 4312, https://doi.org/10.1029/2001JD001102, 2002.

Nedelec, P., Cammas, J.-P., Thouret, V., Athier, G., Cousin, J.-M., Legrand, C., Abonnel, C., Lecoeur, F., Cayez, G., and Marizy, C.: An improved infrared carbon monoxide analyser for routine measurements aboard commercial Airbus aircraft: technical validation and first scientific results of the MOZAIC III programme, Atmos. Chem. Phys., 3, 1551-1564, https://doi.org/10.5194/acp3-1551-2003, 2003.

O'Keefe, A., Scherer, J. J., and Paul, J. B.: CW Integrated cavity output spectroscopy, Chem. Phys. Lett., 307, 343-349, https://doi.org/10.1016/S0009-2614(99)00547-3, 1999.

Park, M., Randel, W. J., Kinnison, E. J., Garcia, R. R., and Choi, W.: Seasonal variation of methane, water vapor and nitrogen oxides near the tropopause: Satellite observations and model simulation, J. Geophys. Res., 109, D03302, https://doi.org/10.1029/2003JD003706, 2004.

Park, M., Randel, W. J., Emmons, L. K., and Livesey, N. J.: Transport pathways of carbon monoxide in the Asian summer monsoon diagnosed from Model of Ozone and Related Tracers (MOZART), J. Geophys. Res., 114, D08303, https://doi.org/10.1029/2008JD010621, 2009.

Pinty, J. P. and Jabouille, P.: A mixed-phased cloud parametrization for use in a mesoscale non-hydrostatic model: Simulations of a squall line and of orographic precipitation, in: Proc. of the Conference on Cloud Physics, 17-21 August 1998, Am. Meteorol. Soc., Boston, Everett, WA, USA, 217-220, 1998.

Randel, W. J. and Park, M.: Deep convective influence on the Asian summer monsoon anticyclone and associated tracer variability observed with Atmospheric Infrared Sounder (AIRS), J. Geophys, Res., 111, D12314, https://doi.org/10.1029/2005JD006490, 2006.

Randel, W. J., Wu, F., Gettelman, A., Russell, J. M., Zawodny, J. M., and Oltmans, S. J.: Seasonal variation of water vapour in the lower stratosphere observed in Halogen Occultation Experiment data, J. Geophys. Res., 106, 14313-14325, https://doi.org/10.1029/2001JD900048, 2001.

Randel, W. J., Park, M., Emmons, L., Kinnison, D., Bernath, P., Walker, K. A., Boon, C., and Pumphrey, H.: Asian monsoon transport of pollution to the stratosphere, Science, 328, 611-613, https://doi.org/10.1126/science.1182274, 2010.

Rasch, P. J., Tilmes, S., Turco, R. P. Robock, A., Oman, L., Chen, C. C., Stenchikov, G. L., and Garcia, R. R.: An overview of geoengineering of climate using stratospheric sulphate aerosols, Philos. T. Roy. Soc. A, 366, 4007-4037, https://doi.org/10.1098/rsta.2008.0131, 2008.

Rothman, L. S. Gordon, I. E., Babikov, Y., Barbe, A., Chris Benner, D., Bernath, P. F., Birk, M., Bizzocchi, L., Boudon, V., Brown, L. R., Campargue, A., Chance, K., Cohen, E. A., Coudert, L. H., Devi, V. M., Drouin, B. J., Fayt, A., Flaud, J. M., Gamache, R. R., Harrison, J. J., Hartmann, J. M., Hill, C., Hodges, J. T., Jacquemart, D., Jolly, A., Lamouroux, J., Le Roy, R. J., Li, G., and Long, D. A.: The HITRAN2012 molecular spectroscopic database, J. Quant. Spectrosc. Ra., 130, 4-50, https://doi.org/10.1016/j.jqsrt.2013.07.002, 2013.

Saunders, R., Hocking, J., Rundle, D., Rayer, P., Matricardi, M., Geer, A., Lupu, C., Brunel, P., and Vidot, J.: RTTOV-11 - Science and validation report, NWP SAF Tech. Rep., 62 pp., avail- 
able at: https://www.nwpsaf.eu/site/download/documentation/ rtm/docs_rttov11/rttov11_svr.pdf (last access: 1 March 2021), 2013.

SEDOO: AERIS, available at: https://aeris-data.fr, last access: 1 March 2021.

Shu, C. W. and Osher, S.: Efficient implementation of essentially non-oscillatory shock-capturing schemes, J. Comput. Phys., 77, 439-471, https://doi.org/10.1016/0021-9991(88)90177-5, 1988.

Slinn, W.: Atmospheric sciences and power production 1979. Precipitation Scavenging, in: chap. 11, US Department of Energy, Washington, D.C., USA, 1983.

Su, H., Jiang, J. H., Lu, X. H., Penner, J. E., Read, W. G., Massie, S., Schoeberl, M. R., Colarco, P., Livesey, N. J., and Santee, M. L.: Observed Increase of TTL Temperature and Water Vapor in Polluted Clouds over Asia, J. Climate, 24, 2728-2736, https://doi.org/10.1175/2010jcli3749.1, 2011.

Suhre, K., Mari, C., Bates, T., Johnson, J., Rosset, R., Wang, Q., Bandy, A., Blake, D., Businger, S., Eisels, F., Huebert, B., Kok, G., Mauldin, R. I., Prévôr, A., Schillawski, R., Tanner, D., and Thornton, D.: 1998, Physico chemical modeling of the first aerosol characterization experiment (ACE 1) Lagrangian B: 1. A moving column approach, J. Geophys. Res., 103, 16433-16455, https://doi.org/10.1029/98JD00821, 1998.

Thouret, V., Marenco, A., Logan, J. A., Nédélec, P., and Grouhel, C.: Comparisons of ozone measurements from the MOZAIC airborne program and the ozone sounding network at eight locations, J. Geophys. Res., 103, 25695-25720, https://doi.org/10.1029/98JD02243, 1998.

Tost, H., Jöckel, P., Kerkweg, A., Pozzer, A., Sander, R., and Lelieveld, J.: Global cloud and precipitation chemistry and wet deposition: tropospheric model simulations with ECHAM5/MESSy1, Atmos. Chem. Phys., 7, 2733-2757, https://doi.org/10.5194/acp-7-2733-2007, 2007.

Tulet, P., Crassier, V., Solmon, F., Guedalia, D., and Rosset, R.: Description of the MESOscale NonHydrostatic Chemistry model and application to a transboundary pollution episode between northern France and southern France, J. Geophys. Res., 108, 4021, https://doi.org/10.1029/2000JD000301, 2003.

Tulet, P., Crassier, V., Cousin, F., Suhre, K., and Rosset, R.: ORILAM, a three-moment lognormal aerosol scheme for mesoscale atmospheric model: Online coupling into the Meso-chemNH-C model and validation on the Escompte campaign, J. Geophys. Res., 110, D18201, https://doi.org/10.1029/2004JD005716, 2005.
Tulet, P., Grini, A., Griffin, R. J., and Petitcol, S.: ORILAM-SOA: A computationally efficient model for predicting secondary organic aerosols in three-dimensional atmospheric models, J. Geophys. Res., 111, D23208, https://doi.org/10.1029/2006JD007152, 2006.

Tulet, P., Crahan-Kaku, K., Leriche, M., Aouiwerats, B., and Crumeyrolle, S.: Mixing of dust aerosols into a mesoscale convective system: Generation, filtering and possible feedbacks on ice anvils, Atmos. Res., 96, 302-314, https://doi.org/10.1016/j.atmosres.2009.09.011, 2010.

Ulanovsky, A. E., Yushkov, V. A., Sitnikov, N. M., and Ravegnani, F.: The FOZAN-II fast-response chemiluminescent airborne ozone analyser, Instrum. Exp. Tech., 44, 249-256, 2001.

van der Werf, G. R., Randerson, J. T., Giglio, L., Collatz, G. J., Mu, M., Kasibhatla, P. S., Morton, D. C., DeFries, R. S., Jin, Y., and van Leeuwen, T. T.: Global fire emissions and the contribution of deforestation, savanna, forest, agricultural, and peat fires (1997-2009), Atmos. Chem. Phys., 10, 11707-11735, https://doi.org/10.5194/acp-10-11707-2010, 2010.

Vernier, J. P. Fairlie, T. D., Natarajanm, M., Wienhold, F. G., Bian, J., Martinsson, B. G., Crumeyrolle, S., Thomason, L. W., and Bedka, K. M.: Increase in upper tropospheric and lower stratospheric aerosol levels and its potential connection with Asian pollution, J. Geophys. Res.-Atmos., 120, 1608-1619, https://doi.org/10.1002/2014JD022372, 2015.

Wesely, M.: Parameterization of surface resistances to gaseous dry deposition in regional-scale numerical-models, Atmos. Environ., 23, 1293-1304, https://doi.org/10.1016/0004-6981(89)90153-4, 1989.

Wright, J. S., Fu, R., Fueglistaler, S., Liu, Y. S., and Zhang, Y.: The influence of summertime convection over Southeast Asia on water vapor in the tropical stratosphere, J. Geophys. Res., 116, D12302, https://doi.org/10.1029/2010JD015416, 2011.

Yan, R. and Bian, J.: Tracing the boundary layer sources of carbon monoxide in the Asian summer monsoon anticyclone using WRF-Chem, Adv. Atmos. Sci., 32, 943-951, https://doi.org/10.1007/s00376-014-4130-3, 2015.

Yushkov, V., Oulanovsky, A., Lechenuk, N., Roudakov, I., Arshinov, K., Tikhonov, F., Stefanutti, L., Ravegnani, F., Bonafe, U., and Georgiadis, T.: A chemiluminescent analyser for stratospheric measurements of the ozone concentration (FOZAN), J. Atmos. Ocean. Tech., 16, 1345-1350, 1999. 